With 2 plates

Printed in Great Britain

\title{
A Taxonomic Study of Acinetobacter and Related Genera
}

\author{
By MARGARET J. THOR NLEY* \\ Low Temperature Research Station, Cambridge
}

(Accepted for publication 8 May 1967)

SUMMARY

CONTENTS

INTRODUCTION

Methods

$\begin{array}{lr}\text { Section I. Bacteriological methods } & 2 \text { I4 }\end{array}$

$\begin{array}{lr}\text { I.I. Sources of strains } & 214\end{array}$

$\begin{array}{ll}\text { I.2. Temperature of incubation } & 217\end{array}$

$\begin{array}{ll}\text { I.3. Basal media } & 217\end{array}$

$\begin{array}{ll}\text { 1.4. Morphological observations } & 217\end{array}$

$\begin{array}{ll}\text { I.5. Biochemical and physiological tests } & 218\end{array}$

$\begin{array}{ll}\text { I.5.I. Hugh \& Leifson (1953) test } & 218\end{array}$

$\begin{array}{ll}\text { I.5.2. Antibiotic sensitivity } & 220\end{array}$

Section 2. Computer methods $\quad 220$

2.I. Choice of coding $\quad 22 \mathrm{I}$

2.2. Cluster analysis and representation of results $\quad 22 \mathrm{I}$

2.3. Extraction of differential characters $\quad 222$

2.4. Arrangement of data for computing $\quad 222$

RESULTS

Section I. Arrangement of strains in phenons $\quad 222$

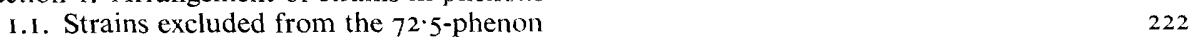

$\begin{array}{ll}\text { 1.2. Subdivision of the } 72 \cdot 5 \text {-phenon } & 225\end{array}$

$\begin{array}{ll}\text { I.3. Phenon I } & 228\end{array}$

$\begin{array}{ll}\text { 1.4. Phenon } 2 & 228\end{array}$

$\begin{array}{lr}\text { 1.5. Phenon } 3 & 229\end{array}$

$\begin{array}{lr}\text { I.6. Phenon } 4 & 230\end{array}$

1.7. Phenon $5 \quad 232$

1.8. Strains within the $72 \cdot 5$-phenon but not included in phenons I-5 232

Section 2. The properties of phenons and individual strains $\quad 232$

2. I. Strains outside the $72 \cdot 5$-phenon

2.2. Strains within the $72 \cdot 5$-phenon 233

2.2.I. The differentiation of phenons $\mathrm{I}-5$ and their subdivisions 233

2.2.I.I. Morphology $\quad 235$

Phenon I $\quad 235$

Phenons 2, 3 and $4 \quad 235$

$\begin{array}{ll}\text { Phenon } 5 & 236\end{array}$

$\begin{array}{ll}\text { 2.2.1.2. Biochemical properties } & 237\end{array}$

$\begin{array}{ll}\text { Subdivisions of phenon } 4 & 237\end{array}$

$\begin{array}{ll}\text { Subdivisions of phenon } 5 & 237\end{array}$

2.2.2. Strains within the $72 \cdot 5$-phenon but not included in phenons $1-5 \quad 239$

$\begin{array}{ll}\text { 2.3. Strains studied after completion of the computer survey } & 239\end{array}$

$\begin{array}{lr}2.4 \text {. Penicillin sensitivity } & 240\end{array}$

* Present address: Sub-Department of Chemical Microbiology, Department of Biochemistry, University of Cambridge. 
Discussion

Section I. General considerations

Section 2. Strains in phenons 2, 3 and 4: the genus Acinetobacter 243

2.1 Taxonomic position : 243

2.2. Nomenclature and definition of the genus 243

2.3. The type species, Acinetobacter anitratus, as represented by the strains in phenon $2 \quad 245$

2.3.1. Nomenclature of the type species $\quad 246$

$\begin{array}{ll}\text { 2.3.2. Evidence from the present work } & 248\end{array}$

2.4. Phenons included in Acinetobacter but not regarded as species $\quad 248$

$\begin{array}{ll}\text { 2.4. I. Phenon } 3 & 248\end{array}$

2.4.2. Phenon $4 \quad 249$

Section 3. Other genera represented in the survey 251

3.1. Alcaligenes 251

3.2. Agrobacterium $\quad 252$

3.3. Achromobacter $\quad 252$

A computer survey was made to find the relationships of 120 strains of Gram-negative or Gram-variable non-motile coccoid rods, isolated by the author and formerly called Achromobacter. They were compared with 75 named strains of various Gram-negative genera, on the basis of morphological properties and biochemical tests. A recently developed similarity coefficient was used and strains were sorted into phenons by single linkage. Most of the strains were grouped at $72.5 \%$ similarity into one large phenon. Strains outside this phenon were: Pseudomonas aeruginosa (2), P. fluorescens (3), P. saccharophila (I), P. putrefaciens (I), Escherichia coli (I), Cellulomonas biazotiea (I), Arthrobacter globiforme (I). These were differentiated from the 72.5 -phenon by various combinations of the following characters which were nearly always negative for strains within the phenon: fermentative metabolism of sugars, pigmentation, production of reducing compounds from gluconate, alkalinity from arginine, hydrolysis of starch or proteins.

Within the $72 \cdot 5$-phenon, five smaller phenons were distinguished, most of them grouped at $82.5 \%$ similarity. The strains in each of these phenons and the characters possessed by a majority of strains and useful for the differentiation of these phenons were:

Phenons $I$ and 5 were Gram-negative motile rods, usually peritrichous.

Phenon I: Agrobacterium sp. (2), Achromobacter hartlebii (I), Agr. tumefaciens (I). Acid was produced oxidatively from glycerol, sucrose, fructose, lactose, arabinose, xylose, galactose and glucose; $\mathrm{H}_{2} \mathrm{~S}$ produced in Kligler medium; the Kovacs oxidase test positive; nitrate reduced; growth on Simmons medium and on Paton medium; no growth on digest agar at $0^{\circ}$ or $37^{\circ}$; not sensitive to $2 \cdot 5$ i.u. of penicillin.

Phenon 5: Alcaligenes faecalis (3), A. viscosus (1), A. denitrificans (1), A. bookeri (1), Alcaligenes sp. (2). Acid not produced from sugars; oxidasepositive; nitrate reduced; growth on Simmons medium; no growth on Paton medium; growth on digest agar at $37^{\circ}$ but not at $0^{\circ}$; litmus milk became alkaline; not sensitive to 2.5 i.u. of penicillin.

Phenons 2, 3 and 4 were Gram-negative coccoid rods, cocci or short rods, often in pairs.

Phenon 2: Bacterium (or Acinetobacter or Achromobacter) anitratum (I0), Achromobacter lacticum (2), Herellea sp. (8), Diplococcus mucosus (6), Moraxella lwoffi (I), MJT isolate (I). Acid not produced from glycerol, sucrose or fructose; oxidative acid production from lactose, arabinose, xylose, galactose and glucose; oxidase-negative; nitrate not reduced; growth on Simmons medium and on Paton medium; growth on digest agar at $37^{\circ}$ but not at $0^{\circ}$; litmus milk became acid; not sensitive to 2.5 i.u. of penicillin. 
Phenon 3: Achromobacter sp. (1), MJT isolates (22). Acid not produced from glycerol, sucrose or fructose; oxidative acid production from lactose, arabinose, xylose, galactose and glucose; oxidase-positive; nitrate reduced; no growth on Simmons or Paton media; growth on digest agar at $0^{\circ}$ but not at $37^{\circ}$; no $\mathrm{pH}$ change in litmus milk; sensitive to 2.5 i.u. of penicillin.

Phenon 4: Mima spp. (7), Achromobacter venenosum (1), Alcaligenes viscosus (2), Moraxella lwoffi (4), Achromobacter sp. (2), Neisseria catarrhalis ( I), MJT isolates (93). Acid not produced from sugars; no growth on Simmons medium; growth on digest agar at $0^{\circ}$ but not at $37^{\circ}$; no $\mathrm{pH}$ change in litmus milk; sensitive to 2.5 i.u. of penicillin. Other characters variable.

Phenons $4 i, 4 i i, 4 i i i$ : small phenons grouped at about $92.5 \%$ similarity within Phenon 4. In properties other than sugar oxidation, Phenon $4 \mathrm{i}$ resembled Phenon 3, and Phenons 4 ii and 4 iii resembled Phenon 2, but not so closely.

The minimum inhibitory concentration of penicillin was estimated for selected strains of Phenons 2, 3 and 4 , and varied from $<0.1$ to $>100$ i.u. $\mathrm{ml}$. Strains of Phenons 3 and $4 \mathrm{i}$ were very sensitive, those of Phenons 2 and 4 iii were resistant, and those of 4 ii were intermediate or resistant. Ungrouped strains of Phenon 4 varied from very sensitive to resistant.

It was concluded, on the basis of these results and the data of Mandel \& Thornley (1967) on DNA composition, that the non-motile coccoid rods in Phenons 2, 3 and 4 should be placed in a separate genus from other strains in the survey. Acinetobacter Brisou \& Prévot is the most suitable generic name, and strains in Phenon 2 correspond to the type species, Acinetobacter anitratus. The relationships of Phenon 3 and the sub-divisions of Phenon 4 need further study, and it is not suggested that they should be given specific rank at present.

Phenons 2, 3 and 4 included strains formerly called Alcaligenes viscosus and Achromobacter; their classification as Acinetobacter entails division of the genera Alcaligenes and Achromobacter. The genus Alcaligenes should be retained for strains resembling the motile, peritrichously flagellate type species, A. faecalis, represented in this study in Phenon 5. It is suggested that the genus Achromobacter also should be reserved for any motile peritrichous strains which may prove suitable for inclusion. The few strains in this survey which had these properties were not very similar to each other, and the borderline between these strains and Agrobacterium was not clear. The strain ATCC I 57I6, proposed as representative of the type species Achromobacter liquefaciens (Tulecke et al. 1965) was unlike all other strains in the survey; ATCC 157I 6 fermented sugars and contained a large proportion of Gram-positive cells, and may be closer to a Gram-positive genus than to those studied here.

\section{INTRODUCTION}

This taxonomic study was prompted by the difficulty of finding a satisfactory way of classifying Gram-negative aerobic non-motile cocci or coccoid rods which were isolated from poultry. In previous papers they have been referred to as Achromobacter (Thornley, I960a; Thornley, Ingram \& Barnes, 1960). Although their properties did not disagree with the extremely vague description of the genus in Bergey's Manual (1957), this classification was not satisfactory because these strains did not resemble the type species, Achromobacter liquefaciens, in motility or other properties, nor did they correspond to any other species listed in Bergey's Manual (1957).

The genus Alcaligenes, as described in Bergey's Manual (1957), appeared to be equally appropriate for all except a small proportion of the strains, which produced 
acid by oxidation of glucose. A new genus, Acinetobacter, was proposed by Brisou \& Prévot (1954) for non-motile bacteria previously classed as Achromobacter or Alcaligenes, and this also seemed a possible place for the isolates from poultry. However, it seemed doubtful whether separation of a genus on the one property of non-motility was justifiable.

This confused situation was reflected in the literature, where bacteria with similar properties, isolated from poultry, were described as 'similar in many respects to Alcaligenes viscosus' (Ayres, Ogilvy \& Stewart, I950) or as belonging to the Achromobacter-Alcaligenes group (Nagel et al. 1960). Similar isolates from fish (Shewan, Hobbs \& Hodgkiss, I960) and from meat (Buttiaux, I96I) were designated Achromobacter by these authors. However, the unsatisfactory nature of this genus, and particularly the lack of any strains corresponding to the type species, has been emphasized by Ingram \& Shewan (1960).

Morphological features resembling those of the poultry isolates have also been mentioned in descriptions of Bacterium anitratum, Mima spp., Herellea spp., Diplococcus mucosus, Moraxella spp. and Neisseria spp. and it was not clear from the literature to what extent some of these groups were closely related or even synonymous.

The main object of the present work was therefore to compare the 'Achromobacter' strains isolated from poultry with named strains of all the genera mentioned. For this the methods of numerical taxonomy proposed by Sneath (I957) seemed particularly suitable. A preliminary study (Thornley, $1960 \mathrm{~b}$ ), by the use of these methods, showed that Pseudomonas strains, including both pigmented and non-pigmented isolates from poultry and from culture collections, could be grouped together and completely separated from 25 'Achromobacter' isolates from poultry. Among the 'Achromobacter' strains three small subgroups appeared, with a fairly low similarity to each other. In the present work it was intended to check the existence of these groups when a much larger number of strains was compared.

One feature of Sneath's (I957) method was its emphasis on positive characters in calculating similarity coefficients; where two strains compared were both negative in any character this did not contribute to the similarity coefficient. It is possible that this caused the much higher similarity found within the group for Pseudomonas strains than for 'Achromobacters' (Thornley, 1960 $b$ ), because the 'Achromobacters' gave fewer positive results. For the present work a new coefficient of similarity, described by J. C. Gower (to be published), was used; this method allows the inclusion of 'negative matches' where it is thought appropriate.

\section{METHODS}

\section{Section I. Bacteriological methods}

\section{I.I. Sources of strains}

The named strains obtained from national or private collections are listed in Table $\mathrm{I}$. Besides the genera thought to be possibly related to 'Achromobacter', strains of some other well-known Gram-negative genera (e.g. Escherichia, Aeromonas, Pseudomonas) were included for reference purposes. Seventy-five named strains were included in the computer survey, and two additional strains were obtained and studied later.

Strains of 'Achromobacter' isolated from poultry carcasses by the author are designated MJT followed by the experiment number, either $\mathrm{F}_{4}$ or $\mathrm{F}_{5}$, then by the 
Table I. Named strains from culture collections included in the survey Strain

no.

Designation and source

Achromobacter anitratus NCTC 8102 (B5W of Stuart, Formal \& McGann, 1949)

A. hartlebii NCIB 8129 (ATCC 365; NRRL B-2392)

A. lacticum NCIB 8208 (NRRL B-55I)

A. lacticum NCIB 8209 (NRRL B-552)

A. venenosum $\mathrm{NCIB} 9022$

Achromobacter EB/F64/100 (Barnes)

Achromobacter CB II (Holding)

Achromobacter 7 A 14 (Holding)

Achromobacter A 16 (Moore)

Achromobacter 131 (Shewan)

Achromobacter I38 (Shewan)

Achromobacter 25 A 2 (Sulzbacher)

Acinetobacter anitratum NCIB 9019 (strain 64 of Brisou, 1957)

Aeromonas formicans (strain 18 of Eddy, 1960)

A. liquefaciens (Pseudomonas hydrophila) NCTC 78I 2 (Eddy, 1960)

Agrobacterium tumefaciens NCIB 8150 (ATCC 4720)

Agrobacterium LK 10 (Holding)

Agrobacterium ZH I (Holding)

Alcaligenes faecalis NCTC 415

A. faecalis NCTC 8764

A. faecalis NCTC 655

A. faecalis NCTC 8769

Alcaligenes sp.

Alcaligenes bookeri NCIB 8I 55

A. denitrificans NCTC 8582 (Leifson \& Hugh, 1954)

A. viscosus NCTC 3233

A. viscosus NCIB 8154 (ATCC 9036)

A. viscosus NCIB 8596

Alcaligenes cs 8 (Holding)

Alcaligenes CS I I (Holding)

Arthrobacter globiformis NCIB 8602 (ATCC 4336)

Bacterium anitratum B 5 (Ontario) strain 705 (Schaub)

B. anitratum B 7 (Ontario) strain EDDY (Schaub)

B. anitratum B 9 (Ontario) strain BIOL 2 (Schaub)

B. anitratum B 10 (Ontario) (strain 90 of Schaub \& Hauber, 1948)

B. anitratum B I I (Ontario) (strain 93 of Schaub \& Hauber, I948)

B. anitratum B I6 (Ontario) NCIB 9293 (strain B5 W3 of Ferguson \& Roberts, 1950)

B. anitratum B 24 (Ontario) (strain B5 w72 of Ferguson \& Roberts, 1950)

B. anitratum B 25 (Ontario) NCIB 930 I (strain B5 W99 of Ferguson \& Roberts, 1950)

Cellulomonas biazotea NCIB 8077 (ATCC 486)

Diplococcus mucosus 169 (Klinge)

D. mucosus oI9 (Klinge)

D. mucosus so I472/6I (Klinge)

D. mucosus so I 506/6I (Klinge)

D. mucosus E 224I/60 (Klinge)

D. mucosus E 8743/60 (Klinge)

Escherichia coli NCTC $900 \mathrm{I}$

Herellea z 6 (Goldberg)

Herellea z 7 (Goldberg)

Herellea z 8 (Goldberg)

Herellea 5937 (King)

Herellea 5939 (King)

Herellea 5942 (King)

Herellea 5944 (King)

Herellea 6009 (King)

Mima $z$ I (Goldberg)

Mima z 2 (Goldberg)

Mima z 3 (Goldberg) 
Strain no.
Table 1 (contd)

Designation and source

\author{
Mima z 4 (Goldberg) \\ Mima 5902 (King) \\ Mima 5936 (King) \\ Mima 5979 (King) \\ Moraxella lwoffi NCTC 5866 \\ M. lwoffi NCTC 5867 \\ M. lwoffi NCTC 7976 \\ M. Iwoffi 950/56 (Klinge) \\ $M$. lwoff I $48 / 57$ (Klinge) \\ Neisseria catarrhalis NCTC 3622 \\ Pseudomonas aeruginosa NCTC 6750 \\ $P$. aeruginosa NCTC 2000 \\ $P$. fluorescens NCTC 4755 \\ $P$. fluorescens NCIB 3756 \\ P. fluorescens $28 / 5$ (Rhodes) (NCTC 10038; NCIB 9046; ATCC I 3525) \\ $P$. putrefaciens NCIB 8615 \\ $P$. saccharophila NCIB 8570 (ATCC 9I I4; NRRL B-1492) \\ Achromobacter sp. NCIB 9650 (strain SKeRMAN 381 of Hendrie et al. 1964, see \\ also Skerman et al. 1958) \\ Achromobacter liquefaciens ATCC I57 16. (Tulecke et al. 1965) \\ * These two strains were studied after the computer survey was made.
}

Dr E. M. Barnes, Low Temperature Research Station, Cambridge.

Dr B. P. Eddy, Low Temperature Research Station, Cambridge.

Professor H.S. Goldberg, Department of Microbiology, University of Missouri, Columbia, Missouri, U.S.A. Strains of Herellea and Mima from human and animal sources.

Dr A. J. Holding, The Edinburgh School of Agriculture, Edinburgh 9. Strains of Achromobacter, Agrobacterium and Alcaligenes from soil.

Dr E. O. King, Communicable Disease Center, Public Health Service, U.S. Department of Health, Education and Welfare, Atlanta, Georgia, U.S.A. Strains of Herellea and Mima from human sources.

Dr K. Klinge, Universität des Saarlandes, Medizinische Fakultät, Institut für Hygiene and Mikrobiologie, Homburg, Germany. Strains of Moraxella lwoffi received from Dr Klinge were isolated by Dr H. Flamm, Hygiene-Institut der Universität, Wien, Austria, and strains of Diplococcus mucosus, were isolated from human sources by Dr F. Legler, Staatliche Bakteriologische Untersuchungs-Anstalt, Erlangen, Germany.

Dr H. B. Moore, Donald N. Sharp Memorial Community Hospital, San Diego, California, U.S.A.

Ontario Department of Health Laboratory, 360 Christie Street, Toronto 4, Ontario, Canada. Strains of Bacterium anitratum originally received from Dr I. Schaub, Johns Hopkins Hospital, Baltimore, Ma. and from Michigan Department of Health, Lansing, Michigan, U.S.A.

Dr M. E. Rhodes, Department of Botany, Coleg Prifysgol Cymru, Aberystwyth.

Dr J. M. Shewan, Torry Research Station, Aberdeen. Strains of Achromobacter from fish.

Dr W. L. Sulzbacher, Bureau of Animal Industry, Agriculture Research Administration. U.S. Department of Agriculture, Beltsville, Maryland, U.S.A.

strain number. Sixty-seven $\mathrm{F}_{4}$ isolates and $53 \mathrm{~F}_{5}$ isolates were examined, and this included the 25 strains previously used (Thornley, 1960 $b$ ). The experiments from which these strains were derived were described by Thornley et al. (I960), together with the differential tests used to separate these bacteria from Pseudomonadaceae and Enterobacteriaceae. Several factors may be of importance in the present study. The poultry-production plants supplying chicken for the two experiments differed in processing methods, so that the respective microfloras might well differ. Most isolates were obtained from carcases after storage at chill temperatures $\left(\mathrm{I}-3^{\circ}\right)$, although some were from initial samples. The effects of irradiation and chlortetracycline treatment 
in delaying bacterial multiplication were studied, and some isolates were from chicken which had received one or both of these treatments.

\section{I.2. Temperature of incubation}

In general, tests were incubated at $20^{\circ}$ except for tests of ability to grow at $0^{\circ}$ and $37^{\circ}$. Some of the bacteria which originated from human sources grew very slowly at $20^{\circ}$ and these were incubated at $25^{\circ}$ with the same times for reading results and finishing the tests. This also applied to six strains isolated from soil and provided by $\operatorname{Dr}$ A. J. Holding.

\subsection{Basal media}

Abbreviations used are as follows: DA, digest agar (Mackie \& McCartney, 1950); YEB and YEA, yeast extract broth and agar, consisting of digest broth with $0.3 \%$ yeast extract added; HIA, Difco Heart Infusion agar; FA, medium B (for maximum fluorescin production) of King, Ward \& Raney (1954).

These media were used as indicated below and in Table 3. In general, the method used was standard for any test, except for a few which were used as preliminary screening tests (observations on colonies, oxidase test, antibiotic sensitivity).

Stock cultures were kept at $5^{\circ}$ in $4 \mathrm{oz}$. (bijou) bottles, on slopes of Collins agar (Barnes \& Thornley, I966); a selection of these cultures has since been freeze-dried. Slopes of HIA medium in I oz. bottles were grown and used for inoculating some test media, while for others, suspensions in $0.85 \%(\mathrm{w} / \mathrm{v}) \mathrm{NaCl}$ solution made from these slopes, or peptone water cultures inoculated from them, were used.

\subsection{Morphological observations}

Organisms were streaked for single colonies on DA or YEA (Expt. F4) or HIA (Expt. F5) media, and the plates incubated for 2 days at $20^{\circ}$ or $25^{\circ}$. These were used for the observations of colony form (Table 2), except for fluorescence which was observed on FA under ultraviolet radiation.

A 24-hr culture in YEB was examined by phase contrast for motility and shape, and then Gram-stained by Kopeloff \& Beerman's modification (Mackie \& McCartney, 1950). Gram-stains were also made on organisms from colonies after incubation for 2 days. The term 'Gram-variable' (Table 2) was used when some organisms in the smear stained Gram-positive and others Gram-negative; this tended to happen particularly with freshly isolated strains.

Organisms were not measured, but their shape was recorded after microscopic observation as follows, length: width ratio greater than $3: 1$ rods, $2-3: 1$ short rods, I-2: I coccoid rods, $1:$ I cocci. Often several shapes were present in one preparation, and sometimes the three observations made for each strain were not all the same. From the information collected the shape which seemed most prevalent for each strain was selected and used for the computer coding.

Flagellar staining by Rhodes's (1958) method was done for most of the motile strains.

A few strains were examined by the electron microscope, with a negative-staining technique (Thornley \& Horne, 1962) to reveal flagella, fimbriae and general morphology. For one strain, thin sections were also prepared, after fixation by the method of Ryter \& Kellenberger (1958). 
Table 2. Computer coding of morphological observations

\begin{tabular}{|c|c|c|c|}
\hline & Colony form & & 1 morphology \\
\hline $\begin{array}{l}\text { Computer } \\
\text { coding* }\end{array}$ & Tests and levels & $\begin{array}{l}\text { Computer } \\
\text { coding* }\end{array}$ & Tests and levels \\
\hline D I & Diffusible pigment & A o & Gram negative \\
\hline$D_{\mathbf{I}}$ & Fluorescence on FA (seen under UV) & 1 & Gram variable \\
\hline A o & Colour white or cream & 2 & Gram positive \\
\hline I & Colour yellow or orange & A o & Rods \\
\hline 2 & Colour brown & I & Short rods \\
\hline A o & Consistency butyrous & 2 & Coccoid rods \\
\hline I & Consistency mucoid & 3 & Cocci \\
\hline 2 & Consistency gluey & $A-$ & No grouping of cells \\
\hline 3 & Consistency coherent & 0 & Pairs \\
\hline A 0 & Edge entire & I & Short chains \\
\hline I & Edge spreading or irregular & 2 & Long chains \\
\hline A o & Surface smooth & 3 & Clumps \\
\hline I & Surface rough or dull & A o & Non-motile \\
\hline 2 & Surface wrinkled, pitted or irregular & I & Motile \\
\hline & & $\mathrm{D}_{\mathrm{I}}$ & Flagella polar \\
\hline & & $\mathrm{D}_{\mathbf{I}}$ & Flagella lateral \\
\hline
\end{tabular}

\subsection{Biochemical and physiological tests}

The methods used, and the computer coding of the results, are listed in Table 3, and will not be described further, except for some details of Hugh \& Leifson's test.

\section{I.5.I. Hugh \& Leifson (1953) test}

The basal medium was made according to Hugh \& Leifson's original formula, and sugar solutions were added after sterilization to a final concentration of $\mathrm{r} \%$. Fructose and sucrose were Seitz-filtered, and other sugars as $15 \%(\mathrm{w} / \mathrm{v})$ aqueous solutions were autoclaved at $115^{\circ}$ for $20 \mathrm{~min}$.

A preliminary test with basal medium + glucose in open and sealed bottles showed whether the metabolism of glucose was fermentative or not. When it was fermentative, both open and sealed bottles of the other sugars were tested. When not fermentative, only open bottles were used, although a further check was made by inspecting these after 2 or 3 days of incubation. Strains which oxidized a sugar then usually showed a layer of acid medium at the top of the bottle only; where there was acid throughout, at first inspection, the test was repeated with a sealed bottle to make sure that the reaction was not fermentative. An open bottle of the basal medium without additions was always inoculated, so that changes in reaction due to metabolism of the peptone were not confused with those caused by metabolism of the sugar.

The results were classed as 'fermentative' where acid was produced in the sealed bottle. Gas production was also noted, but this character was only coded for glucose metabolism, since when produced at all, it was usually produced with every sugar tested. Failure to produce acid was coded as 'inert'. Where acid was produced in the open tube only, developing from the surface downwards, the result was classed as 'oxidative', provided that the open bottle became completely yellow (pH 6 or less) within 14 days. This limit was chosen to exclude extremely feeble and slow acid production, which caused a slight change in the indicator, often at the top of the 
Table 3. Tests used, and computer coding of results

Test

Hugh \& Leifson (1953) test, with glucose, galactose, arabinose, xylose, fructose, sucrose, lactose and glycerol added at $\mathrm{I} \%$

Litmus milk

Milk agar (Smith, Gordon \& Clark, 1946)

Starch agar (Smith et al. 1946)

Loffler serum

Gelatin stab

Blood plate (DA containing $0.5 \%, \mathrm{v} / \mathrm{v}$, horse blood)

$\mathrm{H}_{2} \mathrm{~S}$ from Lemco + cysteine medium (Clarke, I953) with lead acetate paper

$\mathrm{H}_{2} \mathrm{~S}$ production in Kligler medium

Nitrate and nitrite reduction in peptone water $+0.1 \% \mathrm{KNO}_{3}$

Simmons (1926) test for citrate utilization

Paton (1959) medium for gluconate utilization tested with Benedict reagent for reducing compounds

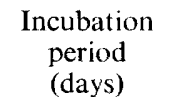

(days)

Computer

14

14

A 0

I

A o

I

2

Q -

I

D I

A 0

I

A 0

I

A 0

14

30

7

I

A 0

I

Q -

I/d

A -

0

I

A o

Q -

I

2

3

14

7

14

10
A o

I

A o

I

A -

I

A 0

I

A 0

I

A -

o
Level observed

Inert

Oxidative

Very slow oxidation

Fermentative

(For each of 8 sugars)

Gas from glucose

Not reduced

Reduced

$\mathrm{pH}$ unchanged

Alkaline

Acid

Reduction absent

Reduction partial

Reduction complete

Clot

Casein unchanged

Casein digested

Starch unchanged

Starch hydrolysed

Unchanged

Cleared or digested

Unchanged

Liquefaction

Liquefaction absent

Liquefaction partial

Where $d$ is no. of days for complete liquefaction

Blood unchanged

Greening

Haemolysis

$\mathrm{H}_{2} \mathrm{~S}$ not formed

$\mathrm{H}_{2} \mathrm{~S}$ formed

$\mathrm{H}_{2} \mathrm{~S}$ not formed

Degree of blackening of indicator

Unchanged

Blackened

$\mathrm{NO}_{3}$ not reduced

$\mathrm{NO}_{3}$ reduced

If $\mathrm{NO}_{3}$ not reduced

$\mathrm{NO}_{2}$ not reduced

$\mathrm{NO}_{2}$ reduced

$\mathrm{pH}$ unchanged

pH alkaline

No growth

Growth

If no growth

Growth, Benedict -

Growth, Benedict + 
Test

Arginine test (Thornley, I960a)

Penicillin sensitivity (2.5 i.u. tablets) (Shewan et al. 1954).

Basal media: YEA for F4 strains, FA for F5

Terramycin sensitivity ( $10 \mu \mathrm{g}$. tablets). Basal media as for penicillin

Kovacs (1956) oxidase test

Ability to grow at $0^{\circ}$. Inoculum streaked across DA plate

Ability to grow at $37^{\circ}$.

Inoculum streaked across DA plate. Growth checked for viability on subculture at $20^{\circ}$
Table 3 (contd)

Incubation
period (days)

Computer coding*

I 4

I, 2

A 0

I

A 0

I

0

$1-12$

I, 2

$\begin{array}{rr}- & \text { A } \\ 14 & \text { I } \\ & \text { A } ~ \\ 7 & \text { I } \\ & \text { A } \\ & \text { I }\end{array}$

Level observed

$\mathrm{pH}$ unchanged or acid pH alkaline Insensitive

Sensitive

$\mathrm{Q}$-Insensitive

Zone $<$ I $\mathrm{mm}$.

Zone size in $\mathrm{mm}$. (zones $>$ $12 \mathrm{~mm}$. coded as 12)

As for penicillin

Negative or slight trace

Positive

No growth, isolated colonies or slight trace Growth

No growth

Slight trace, isolated colonies, or growth not viable when subcultured Growth, viable when subcultured

* D, dichotomies; A, alternatives (qualitatives); Q, quantitatives.

tube only. When such tests were repeated, the same very slight change might be confirmed, or the result might fall into the range classed as 'oxidative' or 'inert'. In the last two cases, the second result was used; but in the first case, or if the test was not repeated, it was coded as 'very slow oxidation' for the computer.

\subsubsection{Antibiotic sensitivity}

For the computer study, the sensitivity of each strain to penicillin and terramycin was tested, using 'Sentest' tablets (Shewan, Hodgkiss \& Liston, 1954). Later, a selection of strains was examined by the gradient plating technique of Szybalski (1952). Benzyl penicillin (Glaxo) was added to Difco Penassay agar at concentrations of $0.5,10$ and 100 i.u./ml., and these mixtures were used to form the wedge-shaped penicillin-containing portion of each plate, to which an equal volume of the same agar without penicillin was later added. Each strain was tested on plates with these three concentrations, and some strains which failed to grow even with the lowest concentration were re-tested on plates prepared with $0 . \mathrm{I}$ i.u. $/ \mathrm{ml}$. in the penicillincontaining portion of the agar. From the results an approximate value for the minimum inhibitory concentration of penicillin for each strain was obtained.

\section{Section 2. Computer methods}

The computing was done by Mr J. C. Gower and Mr G. S. J. Ross, of the Statistics Department, Rothamsted Experimental Station, by using Classification Programme $F_{39}$ for the Elliott 40 I computer; this programme was later re-written and extended as CLASP for the Orion computer. 
The coefficient of similarity used has been described by J. C. Gower (to be published). It allows for the inclusion of quantitative and multivalue qualitative characters as well as dichotomies, for which negative matches do not contribute to the similarity coefficient. The method of coding used for each test is listed in Tables 2 and 3 .

\subsection{Choice of coding}

Tests which are scored as 'positive' or 'negative' can be coded either as dichotomies, so that negative matches are not counted, or as qualitative characters, in which case positive and negative matches contribute equally to the similarity coefficient. Sneath ( 1957) excluded negative matches, while Hill et al. (1961) and Beers \& Lockhart (1962) advocated their inclusion. Since then both methods have been applied by many authors, using various similarity coefficients which were reviewed by Sokal \& Sneath (1963).

The present author considers the inclusion of negative matches more satisfactory, since most tests give arbitrary results, depending on the sensitivity of reagents, conditions of incubation and similar factors. Also, either positive or negative results may have various causes; for instance, negative results could be due to lack of one or more of the enzymes concerned in the reaction, or lack of permeability to the substrate, while positive results in tests such as acid production could be due to different metabolic pathways. In the present work, therefore, positive and negative results have usually been regarded as of equal significance, and coded as qualitative characters (Tables 2 and 3). Where one test is secondary to another, however, the results have been coded so as to avoid duplication of information, and in many cases this may be conveniently done by using dichotomies. For instance, the characters motile or non-motile are coded as qualitative, and possession of polar flagella as a dichotomy, so that their absence should not contribute a second time to the similarity coefficients of pairs of non-motile strains.

For characters other than those scored as positive or negative, coding presented no problems. Only a few tests were suitable for the quantitative treatment (Table 3), and the qualitative method was obviously applicable to tests giving alternative results of equal significance; for instance, shape of organisms or colour of colonies (Table 2).

\subsection{Cluster analysis and representation of results}

After calculation of the matrix of similarity coefficients between all pairs of strains, the strains were sorted into clusters by the single linkage method (Sneath, 1957), which is described in detail by Sokal \& Sneath (1963). The data obtained from this process are represented by shaded diagrams of the similarity matrix (Figs. I, 3) and by dendrograms showing the grouping of strains at different degrees of similarity (Figs. 2, 4). The order in which clusters formed at the same similarity value are arranged after the computation is quite arbitrary, and a slight rearrangement, to bring together clusters of high mean similarity, has been incorporated in Figs. $\mathrm{x}-4$.

In order to delimit clusters which could be described and considered as possible taxonomic groups, some simplification was necessary. This was done, as described by Sokal \& Sneath (1963), by choosing degrees of similarity at which well-defined clusters were separate; these were $72.5,82.5$ and $92.5 \%$ similarity in the present work. The arrangement obtained was then slightly modified on the basis of mean similarity, as explained under Results, I.2. 
The terminology of Sneath \& Sokal (1962), in which these clusters or phenetic groups are referred to as 'phenons', has been used. When the term is prefixed by a number (e.g. $72 \cdot 5$-phenon) this shows the highest degree of similarity at which members of the phenon are grouped in the dendrogram.

\subsection{Extraction of differential characters}

From the data used in the computation it is possible to select the characters which have had most effect in separating the phenons formed. These must vary between phenons, and should be as nearly constant as possible within the phenon to be differentiated. The method of selection used was based on that of Sneath (I962, p. 3I 2).

\subsection{Arrangement of data for computing}

The maximum number of strains which the Elliott $40 \mathrm{I}$ computer could deal with was 128 , so the data had to be divided into two computations. As already mentioned, there were minor differences between $\mathrm{F}_{4}$ and $\mathrm{F}_{5}$ strains in the basal media used for a few tests and therefore these sets of strains were dealt with separately. In the first computation, 53 F5 isolates were compared with 75 named strains from culture collections. This gave well-defined phenons from which the representive strains were selected. The second computation contained $67 \mathrm{~F}_{4}$ strains, together with 40 strains from Computation I, including the representative strains from each phenon.

\section{RESULTS}

Section $I$. The arrangement of strains in phenons

Results of both computations are presented as shaded diagrams of the similarity matrix (Figs. I, 3) and dendrograms, somewhat simplified by the use of triangular blocks to represent groups of strains (Figs. 2, 4).

Distinct clusters of strains, represented by triangular areas of darker shading, are visible in Figs. I and 3; their existence is confirmed by the arrangement shown in Figs. 2 and 4 . Figure 2 shows also that most of the strains were associated at $72.5 \%$ similarity, that is, in a $72 \cdot 5$-phenon. This phenon contains all named strains of Agrobacterium, Achromobacter and Alcaligenes, as well as all the poultry 'Achromobacters' and many related groups such as Moraxella, Mima and Bacterium anitratum. The strains from other well-known genera, included for reference, were all outside the $72 \cdot 5$-phenon.

\section{I.I. Strains outside the 72.5-phenon}

These are listed in Table 4, and are the strains of Pseudomonas, Aeromonas, Escherichia, Cellulomonas and Arthrobacter. Their exclusion from the $72 \cdot 5$-phenon means that all similarity values to individual strains within the phenon were less than $72.5 \%$. The mean similarity values for the whole $72 \cdot 5$-phenon to each of the single strains outside it were also calculated (Table 4 ), and showed that none of these strains was closely related to the $72 \cdot 5$-phenon as a whole, the highest mean similarities being $5 \mathrm{I} \cdot 5 \%$ for Escherichia coli NCTC $900 \mathrm{I}$ and $50.0 \%$ for Arthrobacter globiforme NCIB 8602 .

Detailed relationships between strains outside the $72 \cdot 5$-phenon are indicated by the similarities between pairs of strains (Table 4 ) and by the groups shown in Fig. 2. Two Pseudomonas aeruginosa and three P. fluorescens strains (nos. 69-73) were all 


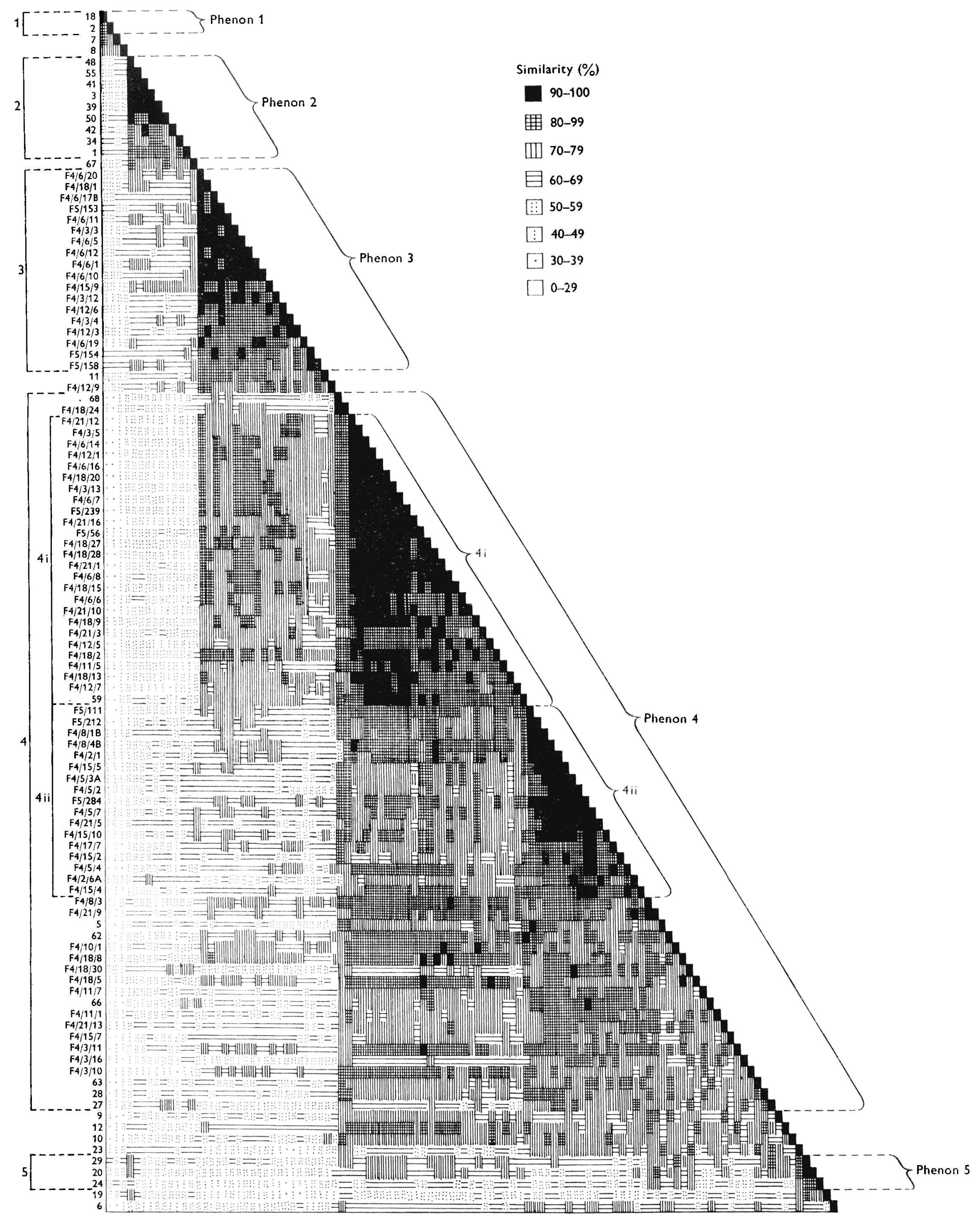

Fig. 3. Similarity matrix for Computation 2. Strains are numbered as in Fig. 1. 


$$
\mathbb{N}
$$




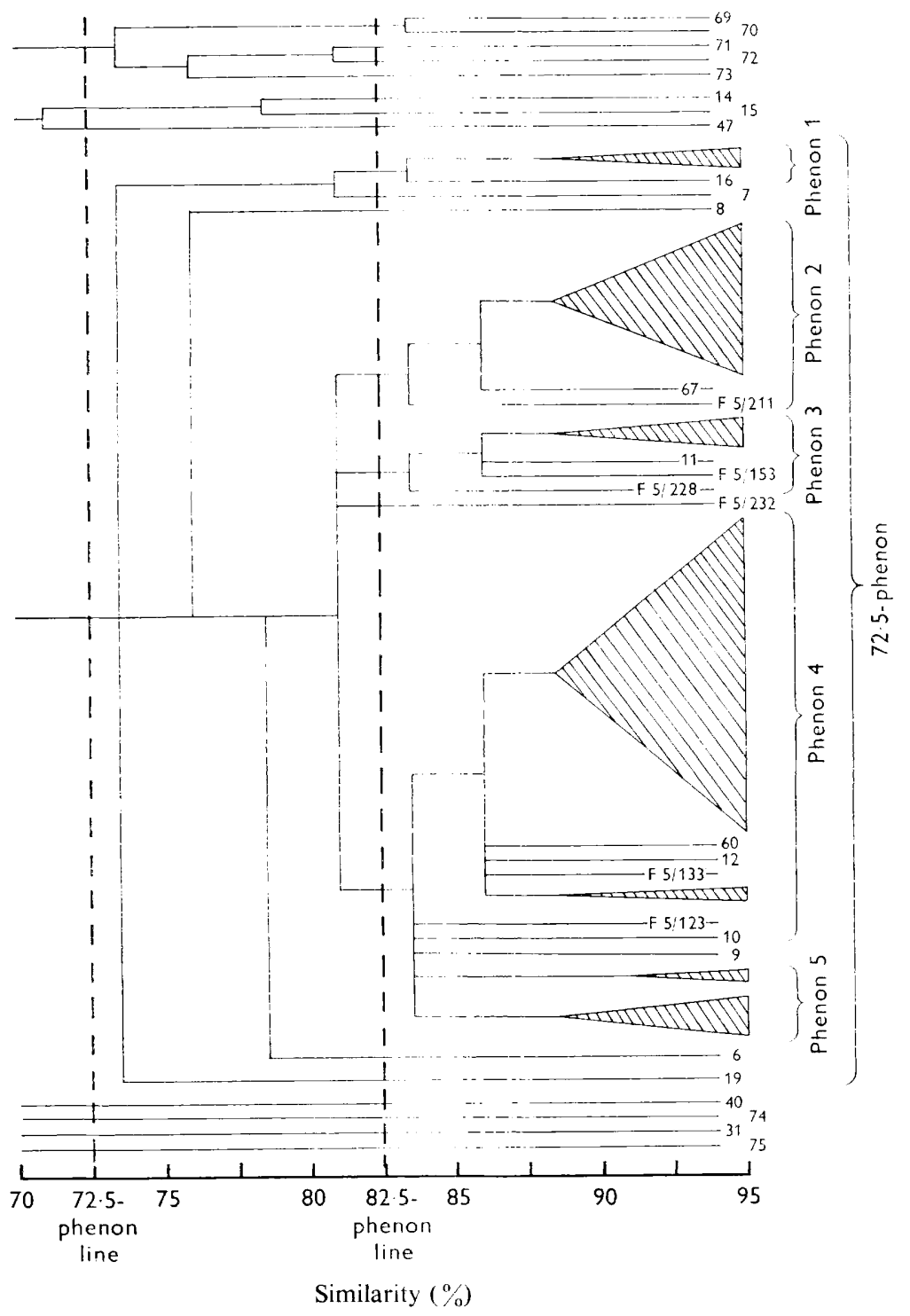

Fig. 2. Dendrogram for Computation 1. Phenons which diverge above $87.5 \%$ similarity are shown by triangles, in which the length of the base is proportional to the number of strains included. Strains are arranged in the same order as in Fig. $\mathbf{I}$.

linked together at $72.5 \%$ similarity, while the two Aeromonas strains (nos. 14, 15) were grouped together at $77.5 \%$ and linked with Escherichia coli (no. 47) at $70 \%$ similarity. Other strains outside the 72.5 -phenon showed no relationships at or above $70 \%$ similarity. Pseudomonas saccharophila NCIB 8570 and $P$. putrefaciens NCIB 86 I 5 (nos. 75, 74) had low similarities to the strains of $P$. aeruginosa and $P$. fluorescens (Table 4). 


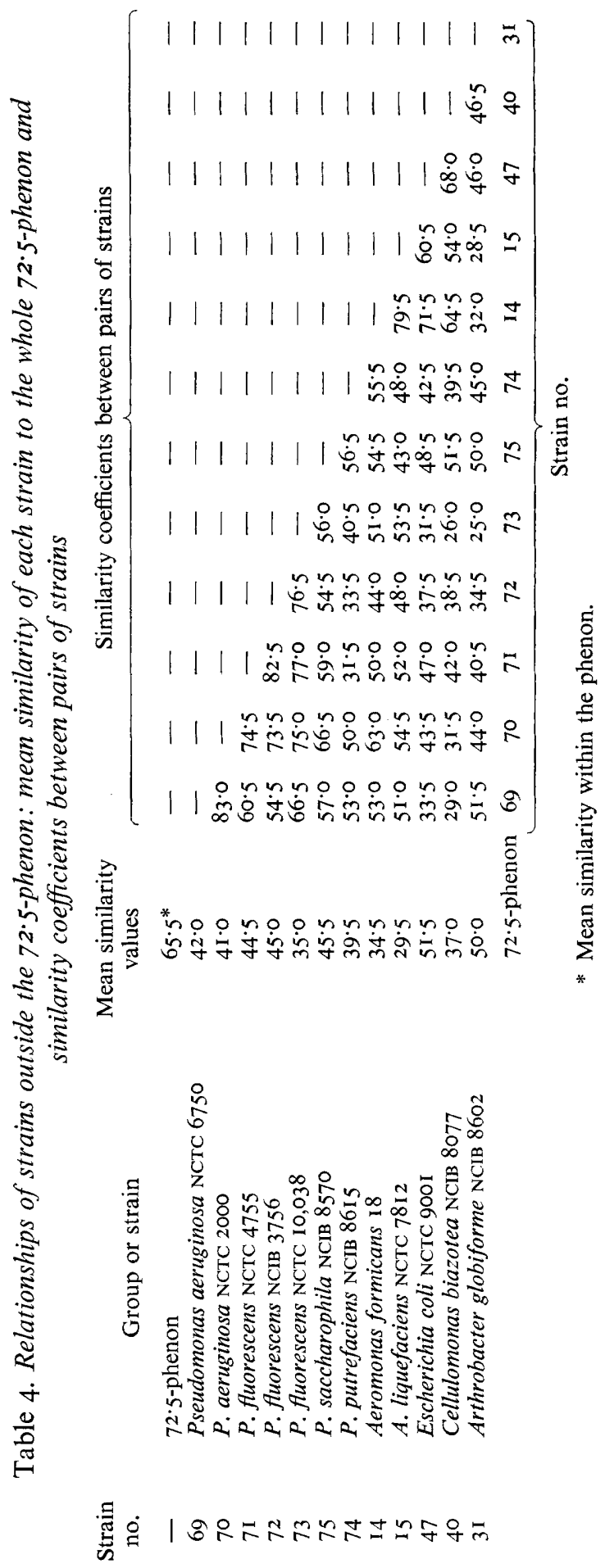




\section{I.2. Subdivision of the 72.5-phenon}

In Computation I the $72 \cdot 5$-phenon contained II 6 strains. Consideration of the dendrogram (Fig. 2) shows that the small group marked Phenon I was separate from the rest of the $72 \cdot 5$-phenon at $75 \%$ similarity, while nearly all other strains remained associated at $80 \%$ similarity. At $82.5 \%$ similarity four phenons were separate, the last being very large and subdivided as Phenons 4 and 5 in Fig. 2. Phenons I-3 in Fig. 2 appeared to be fairly homogeneous distinct clusters in Fig. I, and gave mean similarities within each phenon of $83-85 \%$ (Table 5). When mean similarities of each strain to all other strains in the same phenon were calculated (Table 6), values for strains in Phenons I-3 were mostly above $80 \%$, and none was lower than $75 \%$.

Table 5. Mean similarities within phenons and between phenons

\begin{tabular}{|c|c|c|c|c|c|c|c|}
\hline \multirow{2}{*}{$\begin{array}{c}\text { Compn. } \\
\text { I }\end{array}$} & \multirow{2}{*}{$\begin{array}{c}\text { No. of } \\
\text { strains } \\
4\end{array}$} & \multirow{2}{*}{$\begin{array}{c}\text { Phenon } \\
\text { I }\end{array}$} & \multicolumn{5}{|c|}{ Mean similarities } \\
\hline & & & $85^{\circ} 0$ & - & - & - & - \\
\hline & 28 & 2 & $57 \cdot 0$ & 84.0 & - & - & - \\
\hline & 8 & 3 & 60.5 & $69 \cdot 5$ & 83.0 & - & - \\
\hline & $6 I$ & 4 & $40 \cdot 5$ & $56 \cdot 5$ & 63.5 & $79 \cdot 0$ & - \\
\hline & \multirow[t]{2}{*}{9} & 5 & $52 \cdot 5$ & $55^{\circ} \mathrm{O}$ & $51 \cdot 5$ & 64.5 & $83 \cdot 0$ \\
\hline & & Phenon: & I & 2 & 3 & 4 & 5 \\
\hline \multirow[t]{5}{*}{$2^{*}$} & 9 & 2 & $84 \cdot 0$ & - & - & - & - \\
\hline & 18 & 3 & $67 \cdot 5$ & $88 \cdot 0$ & - & - & - \\
\hline & 64 & 4 & $56 \cdot 5$ & $69 \cdot 5$ & $80 \cdot 5$ & - & - \\
\hline & \multirow[t]{2}{*}{3} & 5 & 54.0 & 53.0 & $65 \cdot 0$ & 87.5 & - \\
\hline & & Phenon: & 2 & 3 & 4 & 5 & - \\
\hline
\end{tabular}

* In Computation 2, Phenon I contained only 2 strains, and has been omitted.

The fourth $82 \cdot 5$-phenon, containing 71 strains, MJT/F5/I2A to 26 (Fig. I), was clearly not homogeneous, and the portion marked Phenon 5 seemed particularly distinct from the rest. The mean similarity for the whole $82 \cdot 5$-phenon (strains MJT/F5/ I $2 \mathrm{~A}$ to 26 ) was $76.0 \%$, and mean similarities for each strain compared with the rest of the phenon ranged from $6 \mathrm{I} \cdot 5$ to $82.0 \%$. Eight strains had mean similarities below $70 \%$, and, of these, seven were in the portion marked Phenon 5. Mean similarities were therefore found separately for the portions marked Phenons 4 and 5 on Figs. I and 2 , and gave within-phenon means of 79.0 and $83.0 \%$ respectively (Table 5). As the mean similarity between Phenons 4 and 5 was only $64.5 \%$, while that between Phenons 2 and 3 was $69.5 \%$ (Table 5), the separation of Phenons 4 and 5 was considered desirable. This appears to be a case where the relationship revealed by the single-linkage method of clustering is not the same as that based on mean similarities, probably because of the existence of intermediate strains, such as strain 9 (Achromobacter AI6). The clustering based on mean similarities was preferred, and Phenons 4 and 5 were considered separately.

The boundaries of Phenons 4 and 5 were therefore also based on mean similarity, which caused the inclusion in Phenon 4 of strains MJT/F5/I23 and Io (see Table 6) and the exclusion of strain 9, which was equally related to Phenons 4 and 5 (Table 8). In Phenon 5 two separate branches of the dendrogram, one of which contained only two strains, were considered together for similar reasons. 
Table 6. Strains within Phenons I-5, arranged in order of highest mean similarity to the other strains in the same phenon

\begin{tabular}{|c|c|c|c|}
\hline Phenon & Mean $\mathrm{S} \uparrow$ & & Strain no. and designation \\
\hline I & $\begin{array}{l}87 \cdot 5 \\
85 \cdot 0 \\
84 \cdot 5 \\
83 \cdot 5\end{array}$ & $\begin{array}{r}18^{*} \\
2^{*} \\
17 \\
16\end{array}$ & $\begin{array}{l}\text { Agrobacterium } \mathrm{ZH} \text { I } \\
\text { Achromobacter hartlebii NCIB } 8129 \\
\text { Agrobacterium } \text { LK IO } \\
\text { A. tumefaciens NCIB } 8150\end{array}$ \\
\hline 2 & $\begin{array}{l}88 \cdot 5 \\
88 \cdot 0 \\
87 \cdot 5 \\
87 \cdot 5 \\
87 \cdot 0 \\
87 \cdot 0 \\
87 \cdot 0 \\
86 \cdot 5 \\
86 \cdot 0 \\
86 \cdot 0 \\
85 \cdot 0 \\
85 \cdot 0 \\
84 \cdot 5 \\
84 \cdot 5 \\
84 \cdot 5 \\
84 \cdot 0 \\
84 \cdot 0 \\
83 \cdot 5 \\
83 \cdot 5 \\
82 \cdot 5 \\
8 \mathrm{I} \cdot 5 \\
8 \mathrm{I} \cdot 0 \\
80 \cdot 5 \\
80 \cdot 5 \\
80 \cdot 5 \\
79 \cdot 0 \\
76 \cdot 0 \\
75 \cdot 0\end{array}$ & $\begin{array}{l}39^{*} \\
3^{*} \\
48^{*} \\
50^{*} \\
38 \\
37 \\
36 \\
41^{*} \\
4 \\
45 \\
55^{*} \\
46 \\
35 \\
51 \\
44 \\
13 \\
43 \\
49 \\
33 \\
54 \\
52 \\
34^{*} \\
42^{*} \\
I^{*} \\
53 \\
32 \\
67^{*} \\
\end{array}$ & 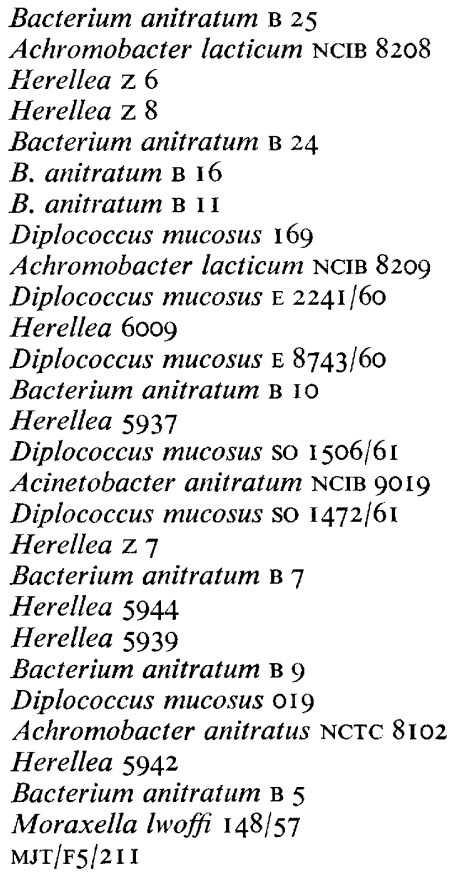 \\
\hline $\begin{array}{c}3 \\
\text { (Compn. I) }\end{array}$ & $\begin{array}{l}86 \cdot 5 \\
84 \cdot 0 \\
84 \cdot 0 \\
83 \cdot 5 \\
80 \cdot 0\end{array}$ & I I $^{*}$ & $\begin{array}{l}\mathrm{MJT} / \mathrm{F} 5 / \mathrm{I} 58^{*} \\
\mathrm{MJT} / \mathrm{F} 5 / \mathrm{I} 54^{*} \\
\mathrm{MJT} / \mathrm{F} 5 / \mathrm{I} 53^{*} \\
4 \mathrm{~F} 5 \text { isolates } \\
\text { Achromobacter } \mathrm{I} 38\end{array}$ \\
\hline $\begin{array}{c}3 \\
\text { (Compn. 2) }\end{array}$ & $\begin{array}{l}92 \cdot 0 \\
92 \cdot 0 \\
90 \cdot 5 \\
90 \cdot 5 \\
90 \cdot 0 \\
90 \cdot 0-85 \cdot 0 \\
85 \cdot 0 \\
84 \cdot 0 \\
83 \cdot 5\end{array}$ & & $\begin{array}{l}\mathrm{MJT} / \mathrm{F} 4 / 6 / 20 \\
\mathrm{MJT} / \mathrm{F} 4 / 6 / 5 \\
\mathrm{MJT} / \mathrm{F} 4 / 6 / 17 \text { B } \\
\mathrm{MJT} / \mathrm{F} 4 / 6 / \mathrm{I} \mathrm{I} \\
\mathrm{MJT} / \mathrm{F} 4 / 153^{*} \\
\mathrm{IO} \mathrm{F} 4 \text { isolates } \\
\mathrm{MJT} / \mathrm{F} 5 / 154^{*} \\
\mathrm{MJT} / \mathrm{F} 4 / 3 / 4 \\
\mathrm{MJT} / \mathrm{F} 5 / 158^{*}\end{array}$ \\
\hline$\stackrel{4}{4}$ & $\begin{array}{l}84 \cdot 5 \\
84 \cdot 5 \\
84 \cdot 5 \\
84 \cdot 5 \\
84 \cdot 0 \\
84 \cdot 0-83 \cdot 0 \\
82 \cdot 5 \\
82 \cdot 5 \\
82 \cdot 5-81 \cdot 0 \\
81 \cdot 0\end{array}$ & $68^{*}$ & $\begin{array}{l}\mathrm{MJT} / \mathrm{F} 5 / \mathrm{III}^{*} \\
\mathrm{MJT} / \mathrm{F} 5 / \mathrm{I} 22 \\
\mathrm{MJT} / \mathrm{F} 5 / 2 \mathrm{I} 2^{*} \\
\mathrm{MJT} / \mathrm{F} 5 / \mathrm{I} 20 \\
\mathrm{MJT} / \mathrm{F} 5 / 284^{*} \\
5 \mathrm{~F} 5 \text { isolates } \\
\mathrm{MJT} / \mathrm{F} 5 / \mathrm{I} 99 \mathrm{~A} \\
\text { Neisseria catarrhalis } \mathrm{NCTC} 3622 \\
7 \mathrm{~F} 5 \text { isolates } \\
\mathrm{MJT} / \mathrm{F} 5 / 238\end{array}$ \\
\hline
\end{tabular}


Table 6 (contd)

\begin{tabular}{|c|c|c|c|}
\hline Phenon & Mean S† & & Strain no. and designation \\
\hline $\begin{array}{c}4 \\
\text { (Compn. I) } \\
(\text { cont. })\end{array}$ & $\begin{array}{l}81 \cdot 0 \\
81 \cdot 0 \\
80 \cdot 5 \\
80 \cdot 5 \\
80 \cdot 0 \\
80 \cdot 0-79 \cdot 5 \\
79 \cdot 5 \\
79 \cdot 0 \\
79 \cdot 0 \\
78 \cdot 5 \\
78 \cdot 5 \\
78 \cdot 0 \\
77 \cdot 5 \\
77 \cdot 0 \\
76 \cdot 5 \\
76 \cdot 5 \\
76 \cdot 0 \\
75 \cdot 5 \\
75 \cdot 5 \\
75 \cdot 0 \\
75 \cdot 0 \\
74 \cdot 5 \\
74 \cdot 0 \\
74 \cdot 0 \\
74 \cdot 0 \\
74 \cdot 0 \\
73 \cdot 5 \\
73 \cdot 0 \\
73 \cdot 0 \\
72 \cdot 5\end{array}$ & $\begin{array}{l}59^{*} \\
\\
5^{*} \\
62^{*} \\
56 \\
28^{*} \\
57 \\
61 \\
66^{*} \\
27^{*} \\
64 \\
58 \\
65 \\
12^{*} \\
63^{*} \\
60 \\
10^{*} \\
\end{array}$ & $\begin{array}{l}\text { MJT/F5/56* } \\
\text { Mima Z } 4 \\
\text { MJT/F5/239* } \\
\text { MJT/F5/136 } \\
\text { MJT/F5/14 } \\
8 \mathrm{~F} 5 \text { isolates } \\
\text { Achromobacter venenosum NCIB } 9022 \\
3 \mathrm{~F} 5 \text { isolates } \\
\text { Mima } 5979 \\
\text { Mima Z I } \\
\text { MJT/F5/236 } \\
\text { Alcaligenes viscosus NCIB } 8596 \\
2 \text { F5 isolates } \\
\text { Mima Z } 2 \\
\text { Mima } 5936 \\
\text { MJT/F5/76 } \\
\text { Moraxella lwoffi } 950 / 56 \\
2 \text { F5 isolates } \\
\text { Alcaligenes viscosus NCIB } 8154 \\
\text { Moraxella lwoffi NCTC } 5867 \\
\text { MJT/F5/I26 } \\
\text { Mima Z } 3 \\
\text { MJT/F5/I23 } \\
\text { MJT/F5/133 } \\
\text { Moraxella lwoffi NCTC } 7976 \\
\text { Achromobacter } 25 \mathrm{~A} 2 \\
\text { Moraxella lwoffi NCTC } 5866 \\
\text { Mima } 5902 \\
\text { Achromobacter I } 31 \\
\text { MJT/F5/I2 A }\end{array}$ \\
\hline $\begin{array}{c}4 \\
\text { (Compn. 2) }\end{array}$ & $\begin{array}{l}86 \cdot 0 \\
85 \cdot 5 \\
85 \cdot 5 \\
85 \cdot 5 \\
85 \cdot 0-84 \cdot 5 \\
84 \cdot 5 \\
84 \cdot 0 \\
84 \cdot 0-83 \cdot 5 \\
83 \cdot 5 \\
83 \cdot 0 \\
83 \cdot 0 \\
83 \cdot 0 \\
82 \cdot 5 \\
82 \cdot 5-82 \cdot 0 \\
82 \cdot 0 \\
81 \cdot 5 \\
81 \cdot 0 \\
81 \cdot 0 \\
80 \cdot 5 \\
80 \cdot 5 \\
80 \cdot 5-76 \cdot 5 \\
76 \cdot 5 \\
76 \cdot 5 \\
76 \cdot 0 \\
75 \cdot 5 \\
75 \cdot 0 \\
75 \cdot 0-73 \cdot 0 \\
71 \cdot 0 \\
71 \cdot 0\end{array}$ & $\begin{array}{l}62^{*} \\
66^{*} \\
28^{*} \\
63^{*} \\
5^{*} \\
27^{*}\end{array}$ & $\begin{array}{l}\mathrm{MJT} / \mathrm{F} 4 / 8 / 4 \mathrm{~B} \\
\mathrm{MJT} / \mathrm{F} 5 / 56^{*} \\
\mathrm{MJT} / \mathrm{F} 4 / \mathrm{I} 8 / 27 \\
\mathrm{MJT} / \mathrm{F} 4 / 6 / 7 \\
7 \mathrm{~F} 4 \text { isolates } \\
\mathrm{MJT} / \mathrm{F} 5 / 239^{*} \\
\mathrm{MJT} / \mathrm{F} 5 / 284^{*} \\
2 \mathrm{~F} 4 \text { isolates } \\
\text { Mima } \mathrm{Z} 4 \\
\mathrm{MJT} / \mathrm{F} 5 / \mathrm{I} \mathrm{I}^{*} \\
\mathrm{MJT} / \mathrm{F} 4 / 5 / 7 \\
2 \mathrm{~F} 4 \text { isolates } \\
\mathrm{MJT} / \mathrm{F} 4 / 8 / 3 \\
4 \mathrm{~F} 4 \text { isolates } \\
\mathrm{MJT} / \mathrm{F} 5 / 2 \mathrm{I} 2^{*} \\
7 \mathrm{~F} 4 \text { isolates } \\
\text { Neisseria catarrhalis } \mathrm{NCTC} 3622 \\
3 \mathrm{~F} 4 \text { isolates } \\
\mathrm{MJT} / \mathrm{F} 4 / 2 \mathrm{I} / 9 \\
\text { Mima } 5979 \\
\mathrm{I} 6 \mathrm{~F} 4 \text { isolates } \\
\text { Moraxella lwoffi } 950 / 56 \\
\text { MJT/F4/2/6 A } \\
\text { Alcaligenes viscosus } \mathrm{NCIB} 8596 \\
\text { Moraxella lwoffi NCTC } 5866 \\
\text { Achromobacter venenosum } \mathrm{NCIB} 9022 \\
2 \text { F4 isolates } \\
\text { Alcaligenes viscosus } \text { NCIB } 8154 \\
\text { MJT/F4/3/I6 }\end{array}$ \\
\hline
\end{tabular}


Table 6 (contd)

$\begin{array}{cc}\text { Phenon } & \text { Mean S† } \\ 5 & 86.5 \\ & 86.0 \\ 85.0 \\ 83.5 \\ 82.0 \\ 82.0 \\ 81 \cdot 0 \\ 80.5 \\ 78.0\end{array}$

Strain no. and designation

20* A. faecalis NCTC 8764

29* Alcaligenes cs 8

26 A. viscosus NCTC 3233

30 Alcaligenes CS II

21 A. faecalis NCTC 655

25 A. denitrificans NCTC 8582

24* A. bookeri NCIB 8155

23* Alcaligenes $\mathrm{sp}$.

22 A. faecalis NCTC 8769

* Indicates strains included for reference in both computations.

$\uparrow$ Mean similarity of the strain indicated to the other strains in the same phenon.

Strains having the highest mean similarity to other strains in the same phenon (Table 6) were regarded as representative strains.

When selecting strains for Computation 2, strains outside the $72 \cdot 5$-phenon of Computation I were not included. Representative strains from each of the five smaller phenons, together with other named strains of particular interest from Computation $\mathrm{I}$, were compared with 67 additional poultry isolates, from the $\mathrm{F}_{4}$ experiment.

The picture obtained (Figs. 3, 4) was in general similar to that from Computation I, with well-defined clusters which could be identified with the phenons of Computation I by the presence of the representative strains. In both computations almost all the poultry isolates appeared in Phenons 3 and 4, and, as the only additional material in Computation 2 was the collection of poultry isolates from Expt. $\mathrm{F}_{4}$, it follows that only the relationships of Phenons 3 and 4 might be expected to differ appreciably. In fact, these two phenons were rather more closely related in Computation 2, both on the dendrogram, where they were linked at $85 \%$ similarity (Fig. 4) compared with $80 \%$ similarity in Fig. 2, and on the basis of mean similarity between the two phenons, which was $69.5 \%$ compared with $63.5 \%$ in the earlier computation (Table 5). Relationships with the other phenons were, however, much the same as in the first computation (Table 5).

In the detailed results which follow, descriptions of Phenons I, 2 and 5 are based on the data from Computation I, since these phenons consisted almost entirely of named strains, and were more fully represented in this computation. For Phenons 3 and 4, containing a large proportion of poultry isolates, data from the two computations have been combined. Table 6 lists the strains included in each phenon, in decreasing order of mean similarity to the other strains in the phenon.

\section{I.3. Phenon $I$}

Representative strain: I8 Agrobacterium ZH I. This phenon contained the three strains of Agrobacterium included in the survey, and Achromobacter hartlebii NCIB 8 129. The soil Achromobacter CB II (strain 7) was also close to this group but was not included within the limits of $82 \cdot 5 \%$ similarity.

\section{I.4. Phenon 2}

Representative strain: 39 Bacterium anitratum B 25 (B5W99 of Ferguson \& Roberts, 1950). This phenon consisted of 28 strains, mostly of human origin. It included all 


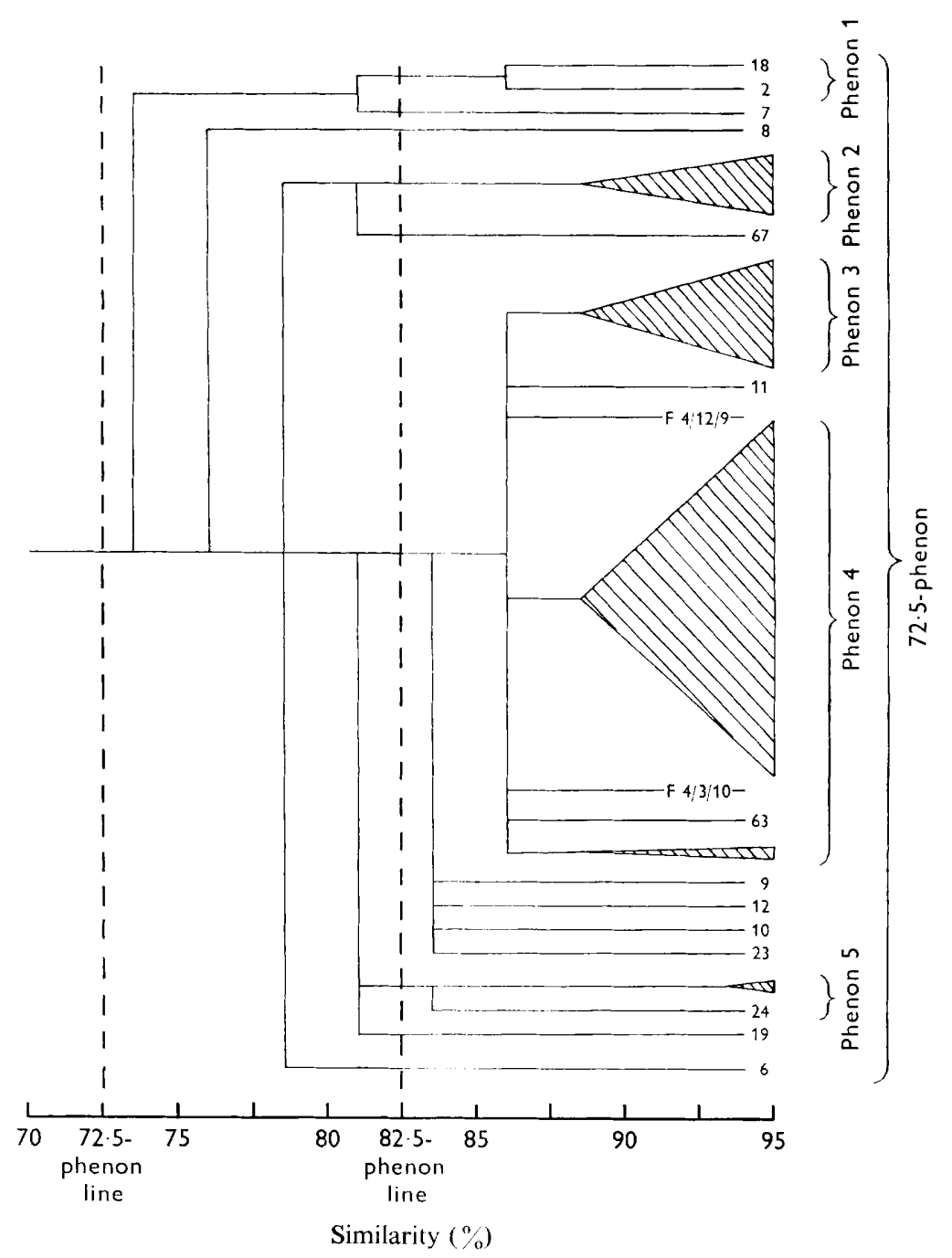

Fig. 4. Dendrogram for Computation 2. Triangles are used as in Fig. 2.

strains named Bacterium (or Achromobacter, or Acinetobacter anitratum (10 strains), Achromobacter lacticum (2 strains), Herellea (8 strains), Diplococcus mucosus (6 strains), one glucose-oxidizing form of Moraxella lwoffi and one glucose-oxidizing poultry isolate. The very close relation between strains named Bacterium anitratum, Achromobacter lacticum, Herellea and Diplococcus mucosus is shown by the fact that representatives of all these appear near the top of the list in Table 6 , with mean similarity values above $86 \%$.

\section{I.5. Phenon 3}

Representative strains: MJT/F5/I58, MJT/F4/6/20. In Computation I this contained only 8 strains, of which 7 were isolated from poultry in Expt. $F_{5}$ and one was from 
fish. The three with highest mean similarities were included in Computation 2, where they were grouped with $I_{5}$ additional strains, isolated from poultry in Expt. $\mathrm{F}_{4}$.

However, the strain with the highest mean similarity in Computation I (MJT/F5/I58) had the lowest mean similarity in Computation 2, which indicates slight differences in properties of $\mathrm{F}_{4}$ and $\mathrm{F}_{5}$ strains belonging to this phenon.

Table 7. Strains within Phenons $4 i, 4 i i$ and 4 iii, arranged in order of highest mean similarity to the other strains in the same phenon

\begin{tabular}{|c|c|c|}
\hline Phenon & Mean S† & $\begin{array}{l}\text { Strain no. and } \\
\text { designation }\end{array}$ \\
\hline $\begin{array}{c}4 \mathrm{i} \\
\text { (Compn. I) }\end{array}$ & $\begin{array}{l}94 \cdot 5 \\
94 \cdot 0 \\
93 \cdot 5-92 \cdot 0 \\
92 \cdot 0 \\
91 \cdot 0-89 \cdot 5 \\
89 \cdot 0\end{array}$ & $\begin{array}{l}\text { MJT/F5/238 } \\
\text { MJT/F5/239* } \\
2 \mathrm{~F} 5 \text { isolates } \\
\text { MJT/F5/56* } \\
4 \mathrm{~F} 5 \text { isolates } \\
59^{*} \text { Mima Z } 4\end{array}$ \\
\hline $\begin{array}{c}4 \mathrm{ii} \\
\text { (Compn. I) }\end{array}$ & $\begin{array}{l}94 \cdot 5 \\
94 \cdot 5 \\
94 \cdot 5-92 \cdot 5 \\
92 \cdot 5 \\
92 \cdot 0-90 \cdot 0 \\
90 \cdot 0 \\
89 \cdot 0\end{array}$ & $\begin{array}{l}\mathrm{MJT} / \mathrm{F} 5 / 122 \\
\mathrm{MJT} / \mathrm{F} 5 / 2 \mathrm{I} 2^{*} \\
7 \mathrm{~F} 5 \text { isolates } \\
\mathrm{MJT} / \mathrm{F} 5 / \mathrm{II} \mathrm{I}^{*} \\
6 \mathrm{~F} 5 \text { isolates } \\
\mathrm{MJT} / \mathrm{F} 5 / 284^{*} \\
\mathrm{I} \mathrm{F} 5 \text { isolate }\end{array}$ \\
\hline $\begin{array}{c}\text { 4iii } \\
\text { (Compn. I) }\end{array}$ & $\begin{array}{l}90 \cdot 5 \\
90 \cdot 0 \\
89 \cdot 5 \\
89 \cdot 5 \\
87 \cdot 5 \\
87 \cdot 5 \\
86 \cdot 0\end{array}$ & $\begin{array}{l}\text { MJT/F5/I4 } \\
\text { MJT/F5/5 } \\
\text { 6I Mima } 5936 \\
56 \text { Mima Z I } \\
57 \text { Mima Z } 2 \\
\text { MJT/F5/I } 5 \\
\text { MJT/F5/96 }\end{array}$ \\
\hline $\begin{array}{c}4 \mathrm{i} \\
\text { (Compn. 2) }\end{array}$ & $\begin{array}{l}94 \cdot 0 \\
94 \cdot 0 \\
94 \cdot 0-93 \cdot 0 \\
92 \cdot 5 \\
92 \cdot 0-88 \cdot 5 \\
88 \cdot 5 \\
88 \cdot 0-86 \cdot 0\end{array}$ & $\begin{array}{l}\mathrm{MJT} / \mathrm{F} 5 / 239^{*} \\
\mathrm{MJT} / \mathrm{F} 4 / 6 / 14 \\
7 \mathrm{~F} 4 \text { isolates } \\
\mathrm{MJT} / \mathrm{F} 5 / 56^{*} \\
8 \mathrm{~F} 4 \text { isolates } \\
59^{*} \text { Mima } \mathrm{Z} 4 \\
7 \mathrm{~F} 4 \text { isolates }\end{array}$ \\
\hline $\begin{array}{c}4 \mathrm{ii} \\
\text { (Compn. 2) }\end{array}$ & $\begin{array}{l}93 \cdot 0 \\
92 \cdot 0 \\
92 \cdot 0-89 \cdot 0 \\
89 \cdot 0 \\
87 \cdot 5-86 \cdot 5 \\
85 \cdot 5 \\
83 \cdot 5\end{array}$ & $\begin{array}{l}\mathrm{MJT} / \mathrm{F} 4 / 5 / 7 \\
\mathrm{MJT} / \mathrm{F} 5 / 284^{*} \\
8 \mathrm{~F} 4 \text { isolates } \\
\mathrm{MJT} / \mathrm{F} 5 / 2 \mathrm{I}^{*} \\
4 \mathrm{~F} 4 \text { isolates } \\
\mathrm{MJT} / \mathrm{F} 5 / \mathrm{III}^{*} \\
\mathrm{I} \mathrm{F} 4 \text { isolate }\end{array}$ \\
\hline
\end{tabular}

* Indicates strains included for reference in both computation.

$\dagger$ Mean similarity of the strain indicated to the other strains in the same phenon.

In the earlier work (Thornley, I960 b) seven strains of 'Achromobacter' were placed in Group A, and, of these strains, six were included in Phenon 3 and one (MJT/F5/232) was close to it (see Table 8). It is evident that Phenon 3 corresponds to Group A of the earlier study.

\section{I.6. Phenon 4}

Representative strain: MJT/F5/III. In Computation I this phenon contained 6I strains, made up of 44 poultry isolates from Expt. F5, Mima (seven strains), Moraxella 
Iwoff (four strains which did not produce acid from sugars), Achromobacter venenosum NCIB 9022, Achromobacter strains 131 and 25A2, and two strains of Alcaligenes viscosus. Neisseria catarrhalis NCTC 3622 was also included, but not so much information was available for comparison here, as the strain did not grow in six of the tests used.

Five poultry strains with high mean similarities, together with several named strains, were included in Computation 2, where they were grouped with 51 isolates from Expt. F4.
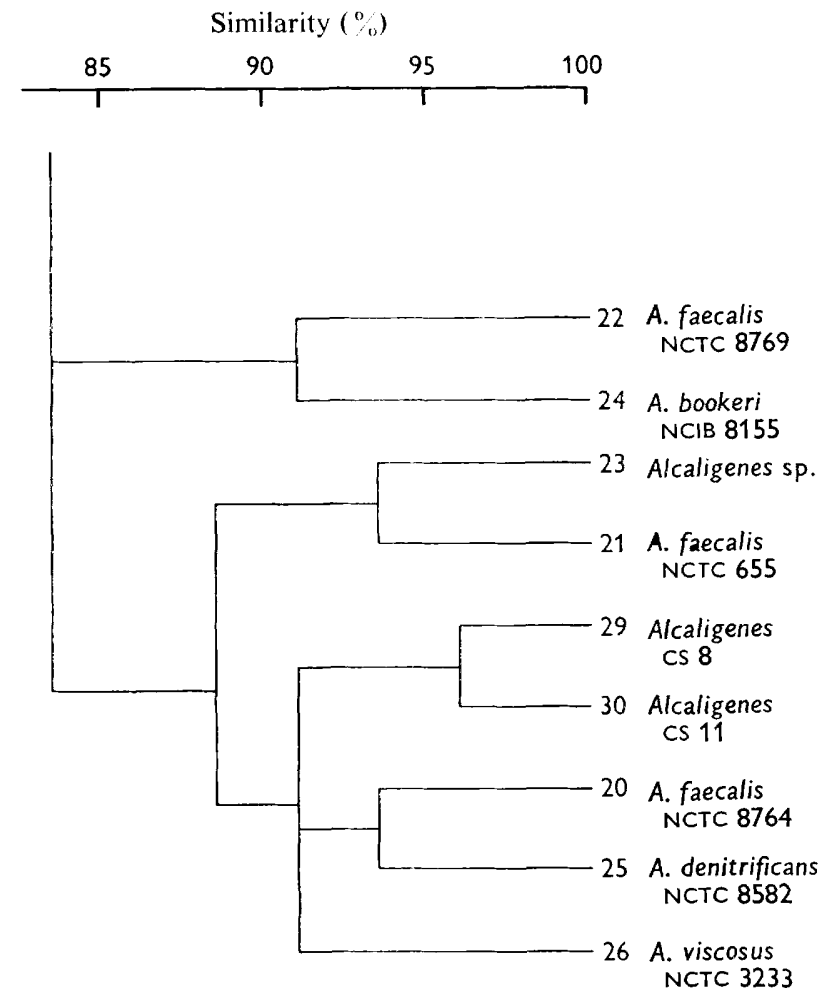

Fig. 5. Detailed dendrogram of Phenon 5, Computation 1, shown by two triangles in Fig. 2.

Several smaller clusters of strains, with very high similarities, were present within Phenon 4, and are indicated in Figs. I and 3. In Computation I, three of these small phenons were apparent: 4i, 4ii, 4iii. Representative strains from Phenons $4 \mathrm{i}$ and 4 ii were included in the second computation, and were present in the phenons labelled $4 \mathrm{i}$ and 4 ii in Fig. 3. Phenon 4 iii did not appear in Computation 2. Three of these small phenons were $92 \cdot 5$-phenons, while the other two (4i, 4 ii, Compn. 1) were based on 92.5 -phenons, but the limits were slightly altered on the basis of mean similarity. Many strains in Phenon 4 were not grouped into any of these small subgroups.

The strains included in Phenons $4 \mathrm{i}-4$ iii are listed in Table 7 , and include poultry isolates, and four strains of Mima, one of which appeared in $4 \mathrm{i}$, and three in 4 iii. Representative strains are: Phenon 4I: MJT/F5/239; Phenon 4ii: MJT/F5/I22, MJT/ 
F4/5/7; Phenon 4 iii: MJT/F5/I4. When the grouping is compared with that of Thornley $(1960 b)$ for 25 isolates from poultry, the same three strains are placed in Group C and Phenon 4iii, which therefore correspond, while the six strains of Group B are divided between $4 \mathrm{i}$ ( 3 strains), 4ii (I strain) and the ungrouped part of Phenon 4 ( 2 strains).

Among the named strains in Phenon 4 , three strains of Mima $(56,57,6 \mathrm{I})$ were grouped in Phenon 4iii, and three strains of Moraxella lwoffi $(63,64,65)$ formed a small 92.5-phenon by themselves (Fig. 1). The two strains of Alcaligenes viscosus $(27,28)$ were linked together at $87.5 \%$ similarity, and with the rest of Phenon 4 at $85 \%$ (Fig. 2). However, their mean similarity values to the rest of the phenon, $78 \%$ and $75.5 \%$ (Table 6), show there is no doubt that they should be included in Phenon 4 . All other named strains in Phenon 4 were scattered singly among the poultry isolates.

Table 8. Strains included in the 72.5-phenon but not in Phenons $1-5$, and their relationships based on mean similarity to phenons

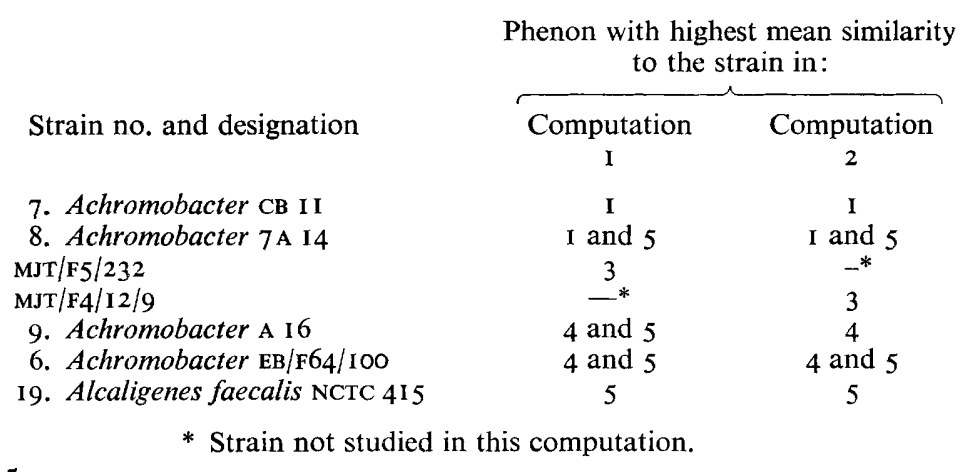

\section{I.7. Phenon 5}

* Strain not studied in this computation.

Representative strain: 20 Alcaligenes faecalis NCTC 8764. Apart from two strains of Alcaligenes viscosus, in Phenon 4, all strains named Alcaligenes were placed in Phenon 5, including three strains received as $A$. faecalis, the type species. Their arrangement according to mean similarity is shown in Table 6 , and the dendrogram (Figs. 2, 5) shows that two small phenons separate at $85 \%$ similarity were included, the first consisting of two strains $(22,24)$ only, and the second being an $87 \cdot 5$-phenon containing seven strains.

Strain 23 was thought, when the testing and computation were done, to be NCIB 8156 (A. faecalis); a culture of this strain obtained later gave different results, but which agreed with those of Hendrie, Hodgkiss \& Shewan (I964). As strain 23 had not been kept, it was impossible to re-test it and its properties have been omitted from Section 2.

\section{I.8. Strains within the 72.5-phenon but not included in Phenons $1-5$}

The closest affinities of these strains are shown in Table 8 , and their properties are given in Section 2.

\section{Section 2. The properties of phenons and individual strains}

All the strains included in this survey were Gram-negative or Gram-variable, did not form spores, were able to grow on HIA or YEA media, and none was an obligate anaerobe. 


\section{I. Strains outside the $72 \cdot 5$-phenon}

Table 9 shows that the characters which were uniform or nearly so throughout the very large $72 \cdot 5$-phenon were all negative. The twelve strains outside this phenon were distinguished by various combinations of positive characters, such as the fermentation of sugars in Hugh \& Leifson medium, pigmentation, production of alkalinity from arginine, and proteolytic properties.

Table 9. Characters which differentiate the $72 \cdot 5$-phenon from strains outside it

\begin{tabular}{|c|c|c|c|c|c|c|c|c|c|c|c|c|c|}
\hline \multirow{3}{*}{ Character } & \multirow{3}{*}{$\begin{array}{l}72 \cdot 5 \text {-phenon } \\
\text { (183 strains) }\end{array}$} & \multicolumn{12}{|c|}{ Strains outside the $72 \cdot 5$-phenon } \\
\hline & & \multicolumn{2}{|c|}{ 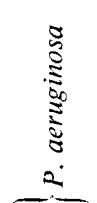 } & \multicolumn{3}{|c|}{ 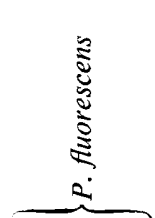 } & \multicolumn{2}{|c|}{ 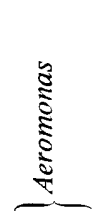 } & \multirow{2}{*}{ 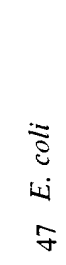 } & \multirow{2}{*}{ 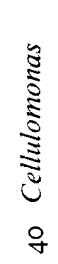 } & \multirow[t]{2}{*}{ 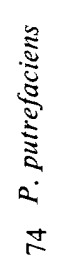 } & \multirow{2}{*}{ 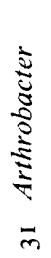 } & \multirow[t]{2}{*}{ 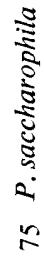 } \\
\hline & & 8 & $\circ$ & $\vec{r}$ & $\mathbb{N}$ & $\stackrel{r}{r}$ & $\Xi$ & $\because$ & & & & & \\
\hline Gas from glucose & - & . & . & . & . & . & . & + & + & . & . & . & . \\
\hline Fermentation of: & & & & & & & & & & & & & \\
\hline Glucose & - & . & . & . & . & . & + & + & + & + & . & . & . \\
\hline Galactose & - & . & . & . & . & . & + & + & + & + & . & . & . \\
\hline Xylose & - & . & . & . & . & . & . & . & . & + & . & . & . \\
\hline Arabinose & - & . & . & . & . & . & + & + & + & + & . & . & . \\
\hline Lactose & - & . & . & . & . & . & + & . & + & + & . & . & . \\
\hline Sucrose & - & . & . & . & . & . & + & + & . & + & . & . & . \\
\hline Fructose & - & . & . & . & . & . & + & + & + & + & . & . & . \\
\hline Glycerol & - & . & . & . & $\dot{.}$ & . & + & + & + & + & . & . & . \\
\hline Fluorescent pigment & - & + & + & + & + & + & . & . & . & . & . & . & . \\
\hline Colony colour: & & & & & & & & & & & & & \\
\hline Yellow & - & . & . & . & . & . & . & . & . & + & . & . & + \\
\hline Brown & - & . & . & . & . & . & . & . & . & . & + & . & . \\
\hline Reducing compounds from & & & & & & & & & & & & & \\
\hline gluconate & - & + & + & . & + & + & . & + & . & . & . & . & . \\
\hline Arginine & $-(98 \%)$ & $t$ & + & $\dot{t}$ & + & + & + & + & . & . & . & . & . \\
\hline Digestion of serum & $-(98 \%)$ & + & + & . & . & + & + & + & . & . & $\dot{+}$ & . & . \\
\hline Casein hydrolysis & $-(98 \%)$ & + & + & . & + & + & + & + & . & . & + & . & . \\
\hline Starch hydrolysis & $-(99 \%)$ & & . & . & . & . & + & + & . & + & . & . & . \\
\hline Gelatine liquefaction & $-(94 \%)$ & + & + & + & + & + & + & + & & + & + & + & + \\
\hline
\end{tabular}

\subsection{Strains within the $72 \cdot 5$-phenon}

\subsection{The differentiation of Phenons $1-5$ and their subdivisions}

Of the characters which varied within the $72 \cdot 5$-phenon, those which had been most effective in separation of Phenons I-5 were selected (Methods, 2.3) and are listed in Table 10 . Characters of no use for differentiation are omitted. The highest discriminatory value was shown by tests which gave different but uniform results in different phenons; only three tests (oxidative acid production from sucrose, fructose and xylose) did this. The discriminatory value of other tests can be judged by the nearness to $100 \%$ of the results for each phenon in Table IO. Such data are useful as a first step in the selection of tests for identification; other criteria which are important for this purpose, such as reproducibility of the tests, were not studied here. 


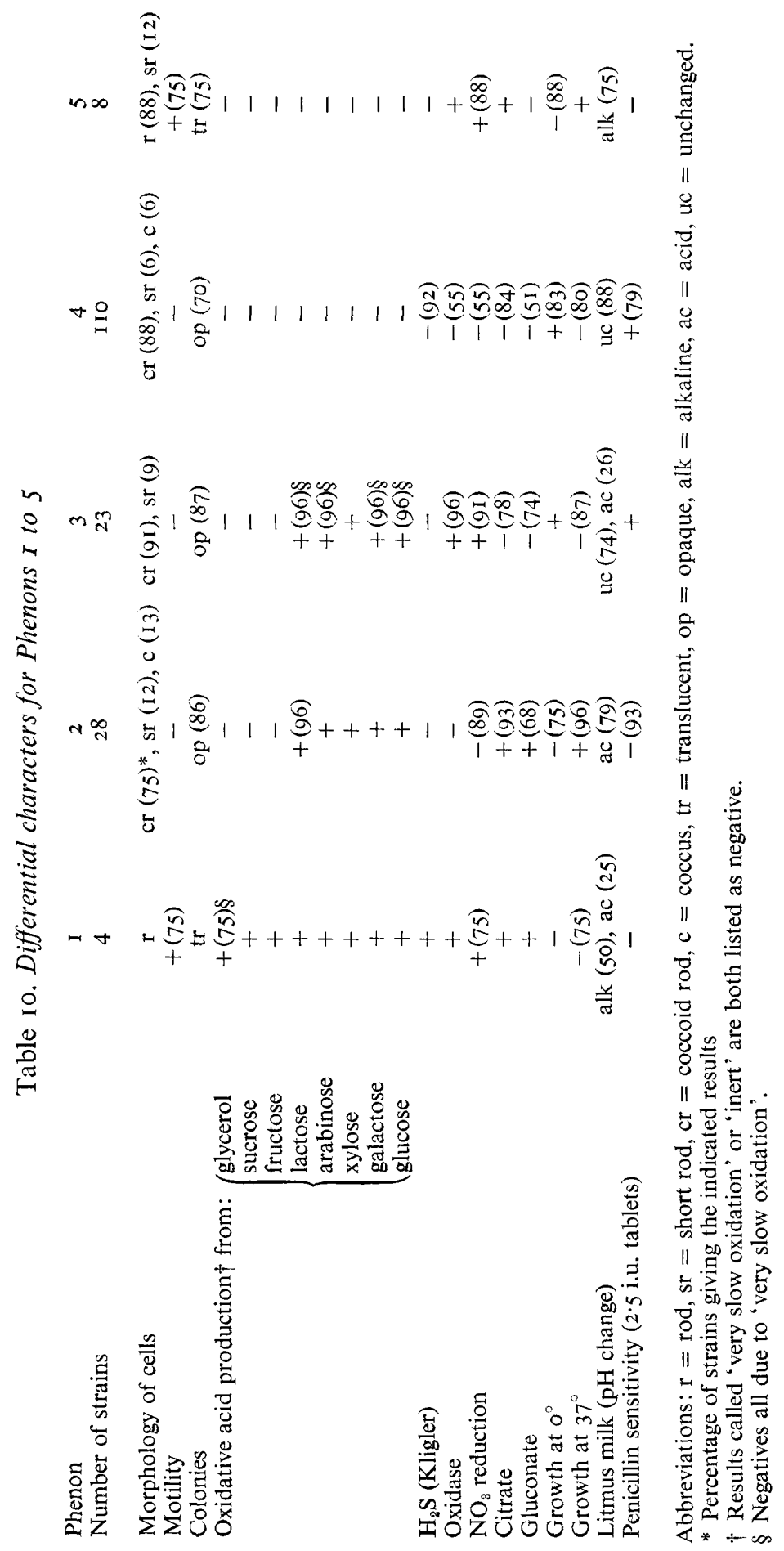




\subsection{I.I. Morphology}

The morphological properties useful in differentiation of phenons can be seen from Table ro. Additional information, mainly based on electron microscopy, is included in this section.

Phenon $I$. The four strains forming this phenon were small rods, of which only three strains were motile in broth (Table 10); the exception, Agrobacterium NCIB 8I50, was motile in Hugh \& Leifson medium.

In the electron microscope one or two lateral flagella per organism were seen on Agrobacterium LK IO. Agrobacterium ZH I was shown to be peritrichous in the electron micrographs of Hendrie et al. (1964), who also reported Achromobacter hartlebii NCIB 8I 29 to be peritrichous; but in the author's flagella stains some organisms had a few lateral flagella while others appeared to have a single polar flagellum. This observation has not been confirmed by electron microscopy, however.

Colonies of all four strains were very small, cream coloured and translucent after incubation for 3 days at $25^{\circ}$ on HIA, and were thus slower growing than almost all others in the survey.

Phenons 2, 3 and 4. Strains in these three phenons were very similar in morphology, and they will be described together. Table 10 shows that all these strains were nonmotile and consisted of coccoid rods, cocci or short rods.

Most strains were Gram-negative, but often appeared a darker red than is usual for Gram-negative bacteria, possibly due to retention of some of the crystal violet. Some of the author's strains from poultry, especially when freshly isolated, showed a proportion of Gram-positive organisms in smears. These strains are referred to as 'Gram-variable', and they formed $13 \%$ of the strains in Phenon 3 and $14 \%$ of strains in Phenon 4.

In shape, the organisms of most strains were classed as coccoid rods by light microscopy (Table 10). Electron microscopy of negatively-stained preparations showed grooves (PI. I, fig. I, $G$ ) where division was taking place, and some organisms were therefore more accurately described as cocci than as coccoid rods. This difference between light microscope and electron microscope observations has been mentioned for similar bacteria by Lemoigne, Girard \& Jacobelli (1952). Strains classed as coccoid rods by light microscopy and cocci by electron microscopy are illustrated in Pl. I, figs. I, 2 and 3, while Pl. 2, fig. 4, shows a strain consisting mainly of coccoid rods, as judged by both methods.

The various named strains which were grouped in Phenon 2 (Table 6) were mostly classed as coccoid rods (Table 10), and this agreed with Klinge's (1959) electron micrographs of strains named Bacterium anitratum, Diplococcus mucosus and Moraxella lwoffi. In both Klinge's work and the present study strains previously named 'Diplococcus' were not more coccoid than the others studied.

Named strains in Phenon 4 included four strains of Moraxella lwoffi, which were short rods; seven strains received as Mima, of which two were cocci and four coccoid rods (by light microscopy); and one strain of Neisseria catarrhalis, which consisted of cocci.

In electron micrographs fimbriae were visible on many strains (Pl. I, figs. I, 2, Pl. 2, fig. 4, F) and also capsular material which appeared dark because of its retention of phosphotungstate (Pl. I, figs. I, 2, C). 
In many strains, organisms were grouped in pairs (P1. I, fig. 2) and small clumps (Pl. I, fig. I); short chains and tetrads were also observed. The two strains of Alcaligenes viscosus, in Phenon 4, showed a tendency to form long chains, which were cocci in NCIB 8596 (Pl. I, fig. 3) and coccoid rods (by electron microscopy) in NCIB 8154. It is not known whether the material connecting the organisms in the chain was mucilaginous, or part of the cell walls.

The grouping of organisms in either short chains or tetrads, due to the direction of successive planes of division being either parallel or perpendicular, has been considered important in classification, the former method being thought characteristic of Moraxella and the latter of Neisseria (Murray \& Truant, I954; Piéchaud, I96I). One poultry strain (MJT/F4/199A) was studied in detail by electron microscopy (Thornley \& Glauert, to be published) and thin sections showed that both methods of division occurred at different stages of the culture. Plate 2, fig. 5 shows a section through a short chain of organisms in a Io hr culture in HIB medium grown with aeration at $25^{\circ}$. An older septum in the centre of the chain divides two pairs of organisms each separated by a more recently formed septum. These septa are all parallel, and this method of division was predominant in this culture. Plate 2, fig. 6 shows the same strain after growth in the same conditions for $24 \mathrm{hr}$ when all groups containing four organisms were in the form of tetrads. Two organisms are united by a recently formed septum. One of them shows a narrow connecting-link to a third organism of the tetrad; this remains from an earlier division at right angles to the latest one.

The colonies produced by strains in Phenons 2, 3 and 4 were generally more opaque than those of Phenons I and 5 (Table I0). The term 'opaque' was relative, and was used when comparing colonies of Gram-negative strains; it was surprising to find a correlation between the predominantly opaque colonies and the coccoid rod morphology, which existed in Phenons 2, 3 and 4. The colonies were cream, and in most strains were smooth, entire and convex, with a butyrous consistency. Some poultry isolates in Phenons 3 and 4 produced colonies with a more gluey consistency, which pulled out into strands when picked with an inoculating needle. An even more coherent form was found in a few poultry isolates of Phenon 4; this latter colony appeared dull and wrinkled, and could only be subcultured by removing the whole colony from the agar plate. One strain in Phenon 4 produced a deep brown diffusible pigment, but was similar to the rest of the phenon in other properties.

Phenon 5. Most strains consisted of rod-shaped organisms, while a few were short rods (Table I0), the shortest being strain 2I, Alcaligenes faecalis NCrC 655 (Pl. 2, fig. 7). Strain 26 (A. viscosus NCrC 3233) consisted of slender tapered rods, some slightly curved; no other organism studied had the same microscopic appearance. Motility in broth cultures was only observed with six of the eight strains (Table 10), but the other two strains (2I, 26) appeared motile in Hugh \& Leifson medium, and strain 21 showed a few lateral flagella (Pl. 2, fig. 7), which confirmed the description of this strain as peritrichous by Hendrie et al. (I964). Fimbriae were also present in this strain (Pl. 2, fig. 7). The flagellation of strain 26 was not determined. Peritrichous flagella were observed for strain 20 (A. faecalis NCTC 8764), 29 (Alcaligenes Cs 8 ) and 30 (Alcaligenes CS II), as stated by Hendrie et al. (1964), and also for strain 25 ( $A$. denitrificans NCTC 8582). The two strains grouped in a small phenon, separate at $85 \%$ similarity from the rest of Phenon 5 (Results, I.7), both had polar flagella. These 
were strain 22 (A. faecalis NCTC 8769 ), previously described as polarly flagellate by Hendrie et al. (1964), and strain 24 (A. bookeri NCIB 8155).

Colonies were usually cream, translucent, smooth and entire, while some were rough, convex in the centre with a thin spreading irregular edge.

2.2.1.2. Biochemical properties. These will not be described for each phenon separately since the differential properties for Phenons I-5 are shown in Table Io. As explained in the Discussion, Phenons 2, 3 and 4 are considered to belong to Acinetobacter, and for convenience all the data on these phenons and their subdivisions are collected in Table I $\mathrm{I}$; the differential properties for the subdivisions of Phenon 4 are marked $\mathrm{D}$ in this table.

The Hugh \& Leifson method of studying sugar metabolism differentiated the following groups of phenons: Phenons 4 and 5, containing strains which produced no acid from the eight compounds studied; Phenons 2 and 3, which showed oxidative acid production from five sugars (glucose, galactose, arabinose, xylose and lactose) and Phenon $\mathbf{I}$, in which most strains produced acid oxidatively from all eight compounds. Production of $\mathrm{H}_{2} \mathrm{~S}$ in Kligler medium was another characteristic of Phenon I which was absent from nearly all strains in other phenons.

A positive result in Kovacs (1956) oxidase test and the ability to reduce nitrate seemed to be correlated among strains within the $72 \cdot 5$-phenon, and positive results were useful in differentiating Phenons I, 3 and 5 from Phenon 2, in which predominantly negative results were found. Strains within Phenon 4 varied in results, as the two tests differentiated the subdivisions of Phenon 4 (Table I I).

Ability to grow with citrate as sole carbon source and an inorganic nitrogen source was present in most strains of Phenons I, 2 and 5, while generally absent in Phenons 3 and 4 (Table 10). Growth with gluconate as sole carbon source was also found in Phenon I, but was less common in Phenons 2 and 5 than was growth with citrate. In Phenons 4 ii and 4 iii, however, most strains could grow with gluconate although not with citrate as sole carbon source (Table II). The majority of strains in Phenons 3 and $4 \mathrm{i}$ failed to grow in either test, and this may have been due to a requirement for organic nitrogen or other growth factors rather than an effect of the carbon source.

Other differential tests for Phenons I-5 were growth temperature, change of $\mathrm{pH}$ in litmus milk and penicillin sensitivity (see Results, 2.4).

Subdivisions of Phenon 4. Differential tests for Phenons $4 \mathrm{i}-4$ iii within Phenon 4 included some of those already mentioned (oxidase, nitrate, gluconate, $\mathrm{pH}$ change in litmus milk and penicillin sensitivity) and, in addition, reduction of litmus milk, production of $\mathrm{H}_{2} \mathrm{~S}$ from cysteine and sensitivity to terramycin.

Nearly all the named strains of Moraxella and Mima included in Phenon 4 differed from the majority of strains in growth temperatures, since they were able to grow at $37^{\circ}$ but not at $0^{\circ}$. In other properties, Mima $\mathrm{z} 4$ resembled the rest of Phenon $4 \mathrm{i}$, except that it was unable to reduce nitrate, three strains of Mima $(56,57,61)$ had properties typical of Phenon 4 iii, and three strains of Moraxella lwoffi (63-65) formed a separate $92 \cdot 5$-phenon with properties listed in Table I I. Other named strains of human origin were scattered singly among the poultry isolates in the ungrouped portion of Phenon 4, indicating that they had different combinations of properties from the subdivisions of the phenons and from each other.

Subdivisions of Phenon 5. The two small phenons within Phenon 5 (Fig. 5) differed 


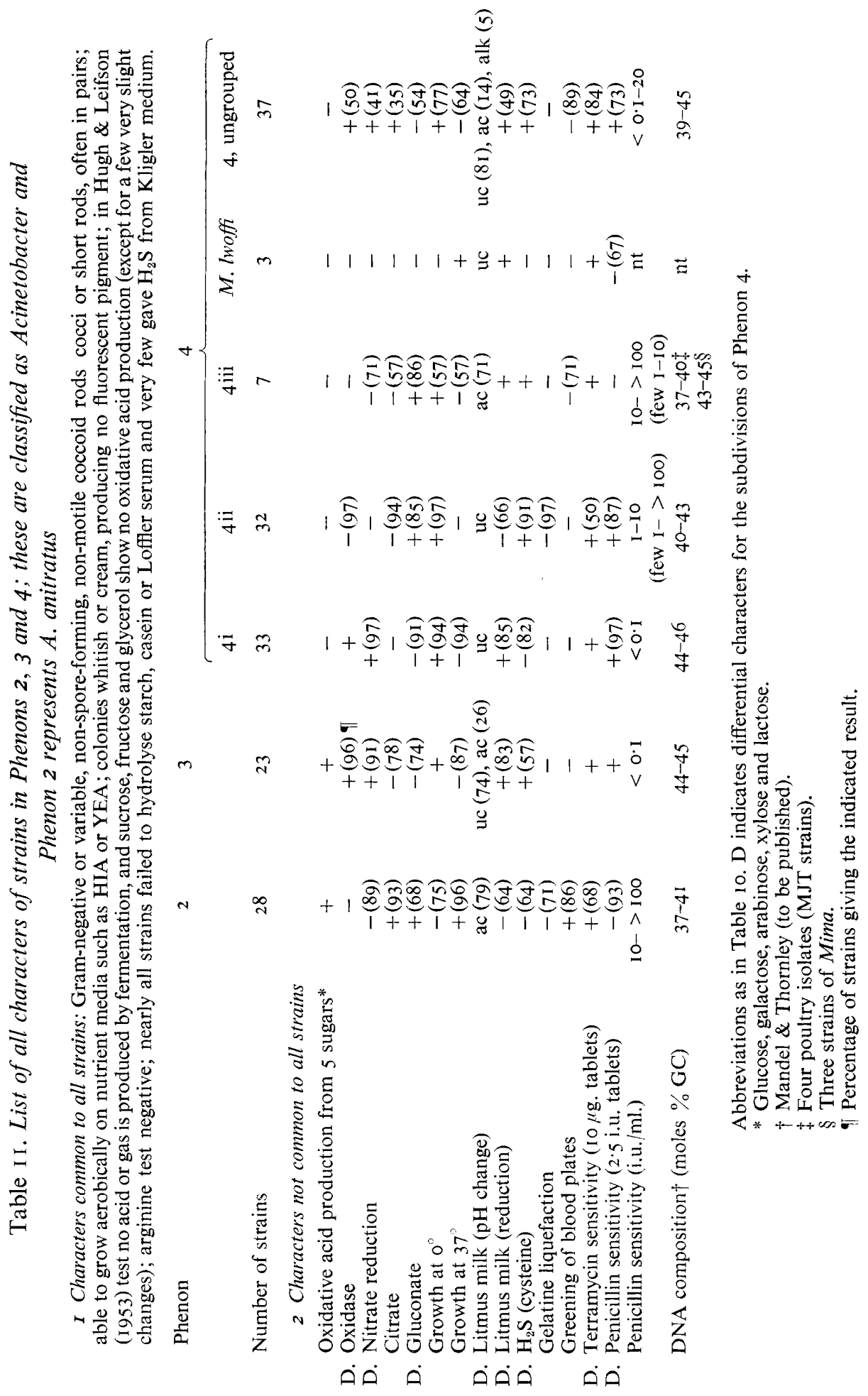


in several properties. Strains 22 and 24 , which formed one of these phenons, possessed polar flagella (Results, 2.2.1), did not produce alkalinity in litmus milk, gave 'very slow oxidation' of fructose, and produced a slow alkaline change in the arginine medium; all these properties distinguished them from the six strains of the other small phenon.

\subsubsection{Strains within the 72.5-phenon, but not included in Phenons I-5}

These are listed in Table 8 , and their properties may be mentioned briefly.

The two Achromobacter strains isolated from soil by Dr A. J. Holding, strains 7 ( $\mathrm{CB}$ I I) and 8 (7A I4) were motile rods, flagella where determined (strain 8) being peritrichous. Strain 7 was closely related to Phenon I, while strain 8 was equally similar to Phenons $I$ and 5. Both strains differed from Phenon I in failure to grow on Paton medium and to produce $\mathrm{H}_{2} \mathrm{~S}$ in Kligler medium. While strain 7 gave similar sugar results to Phenon I, strain 8 was less active, only glucose, galactose and xylose being oxidised, arabinose and glycerol giving the reaction described as 'very slow oxidation', and lactose, sucrose and fructose showing no change.

Strain 9 (A I6 of Moore \& Pickett, 1960a) resembled both Phenons 4 and 5, but differed from both in its ability to liquefy gelatin and Loffler's serum, and the combination of other properties did not fit either phenon.

Strain $6(\mathrm{~EB} / \mathrm{F} 64 / \mathrm{IOO})$ was isolated from poultry, and was a Gram-variable motile rod with peritrichous flagella, forming cream-coloured colonies with spreading feathery outgrowths. This was originally thought to be a motile strain of Achromobacter, but from the computer results it showed little resemblance to any other motile Achromobacter strains, such as strains 7 and 8, and was not closely related to any of the phenons, although nearest to Phenons 4 and 5. It gave no acid from sugars, except for 'very slow oxidation' of glucose, was oxidase-negative, nitrate reductionnegative, did not grow on Simmons or Paton media at $0^{\circ}$, but grew at $37^{\circ}$, showed reduction but no $\mathrm{pH}$ change in litmus milk, and was penicillin-sensitive. Re-examination of the strain showed a large proportion of Gram-positive organisms, particularly when grown on solid medium. It was thought possible that this strain was close to some Gram-positive genus. It was examined by Dr T. Gibson (Edinburgh School of Agriculture), who found it to be a typical Kurthia.

Strain I9 (Alcaligenes faecalis NCTC 415) was not included in any phenon although closest to Phenon 5. When received, this strain showed a mixture of rough and smooth colonies, and was tested without single-colony isolation. Results included 'very slow oxidation' of four sugars and these were the main characters separating this strain from Phenon 5. When a single rough colony was separated, and re-tested (as 4I5A), acid was not formed from sugars and if these results had been included in the computation strain 4I5A would have been placed in Phenon 5; it was most like $A$. faecalis NCTC 8764 , the representative strain of the phenon.

\subsection{Strains studied after completion of the computer survey}

Two strains reported to be similar to Achromobacter liquefaciens became available after the computer survey was made.

Achromobacter sp. NCIB 9650 is the strain described by Hendrie et al. (1964) as SKERMAN 38I, which was studied by Skerman, Carey \& MacRae (I958). Hendrie et al.'s observations, that this was a Gram-negative rod, motile by peritrichous flagella and 
oxidase positive, were confirmed. In my tests, however, it did not liquefy gelatine, one of the few properties mentioned in Eisenberg's (189I) original description of Bacillus liquefaciens. It differed from the amended description of Bergey's Manual (1923) in producing alkalinity in litmus milk, instead of no change. Other properties were as follows: colony cream, rough, with a thin spreading edge, no acid from sugars, nitrate not reduced to nitrite, growth in Simmons medium, not on Paton medium, growth at $37^{\circ}$, no growth at $0^{\circ}$, penicillin-sensitive. When compared with strains used in the computer survey, it was most like the soil strain of Alcaligenes, cs8, from which it differed only in not reducing nitrate and being penicillin-sensitive. Strain Cs8 had a high mean similarity to the rest of Phenon 5 (Table 6). Achromobacter sp. NCIB 9650 was also close to Alcaligenes faecalis NCTC 8764 and NCTC 4I 5A, differing from both in three characters only; resemblances to strains in other phenons were very much lower, and it seems, therefore, that Achromobacter sp. NCIB 9650 should be classified as an Alcaligenes strain.

Tulecke et al. (1965) isolated an organism resembling Achromobacter liquefaciens as described by Eisenberg (I89I) and by Bergey's Manual (I923); this strain is ATCC I57 I6. Tests used by the present author, where similar to those of Tulecke et al., confirmed their results, with a few exceptions. Gram strains on organisms from broth cultures showed Gram-negative short rods, while those from nutrient agar cultures showed more than half the organisms to be Gram-positive. Also, litmus milk became alkaline, and in the conditions used here growth took place at $37^{\circ}$. Gelatine was liquefied and nitrate was not reduced, as reported by Tulecke et al.

The production of acid but no gas from glucose, sucrose and fructose was confirmed; this was shown by the Hugh \& Leifson test to be a fermentative process. Fermentation of xylose, arabinose and galactose also took place, while glycerol gave acid in oxidative conditions only. This strain did not produce $\mathrm{H}_{2} \mathrm{~S}$ in Kligler or cysteine media, was oxidase-negative, gave traces of growth on Simmons medium, no growth on Paton medium, did not grow at $0^{\circ}$ and was sensitive to penicillin and to terramycin. It was negative in effects on arginine medium, blood and starch plates and did not reduce litmus milk. Besides liquefying gelatine, it hydrolysed Loffler's serum and casein.

When compared with strains in the computer survey, ATCC 157 I 6 differed from all strains by 14 characters or more. It was most similar to Escherichia coli, Cellulomonas biazotea, Achromobacter 7A I4, Alcaligenes faecalis NCTC $4 \mathrm{I} 5$ and Achromobacter EB/F64/IOO (later shown to be Kurthia); from all these strains, ATCC 157I6 differed by 14 or 15 characters, and for other strains in the survey, the differences were greater in number.

This organism ATCC I57I6 is therefore very unlike any strains included in the survey. The large proportion of Gram-positive organisms in smears from solid media makes it seem possible that it has closer affinities to some Gram-positive genus than to Gram-negative or Gram-variable groups such as those studied here, and its sensitivity to penicillin is consistent with this.

\subsection{Penicillin sensitivity}

It was evident from the computer survey that sensitivity to 2.5 i.u. tablets of penicillin was a useful differential character (Tables IO, II). Where inhibition zones were formed they varied considerably in size; for instance, both Phenons $4 \mathrm{i}$ and $4 \mathrm{ii}$ contained mostly strains sensitive to $2 \cdot 5$ i.u., but those in Phenon $4 \mathrm{i}$ all formed zones 
larger than $3 \mathrm{~mm}$, whereas in Phenon 4 ii, only $32 \%$ of the sensitive strains produced zones $>3 \mathrm{~mm}$.

The minimum inhibitory concentration (m.i.c.) of penicillin for selected strains was therefore estimated by the gradient plate method, and compared with the zone sizes formed by 2.5 i.u. tablets (Table I 2 ). The m.i.c. was found to vary over a very wide range, from $<0.0$ i.u. $/ \mathrm{ml}$. to $>$ IOO i.u. $/ \mathrm{ml}$, that is, by a factor of more than $10^{4}$. Almost the full extent of this range occurred among strains within Phenon 4.

It was noticeable that the range in m.i.c. was not continuous. Some strains, in

Table I2. Penicillin sensitivity of selected strains: a comparison of results obtained with 2.5 i.u. tablets and by the gradient plate technique

\begin{tabular}{|c|c|c|c|c|}
\hline Phenon & Strain & $\begin{array}{l}\text { Zone } \\
\text { size* } \\
(\mathrm{mm} .)\end{array}$ & $\begin{array}{l}\text { m.i.c. } \dagger \\
\text { (i.u./ml.) }\end{array}$ & Class \\
\hline 2 & $\begin{array}{l}\text { Bact. anitratum } \mathrm{B} 24 \\
\text { Achr. lacticum NCIB } 8208\end{array}$ & $\begin{array}{l}-\mathrm{F},-\mathrm{H} \\
-\mathrm{F},-\mathrm{H}\end{array}$ & $\begin{array}{r}>100 \\
50\end{array}$ & $\begin{array}{l}\mathrm{R} \\
\mathrm{R}\end{array}$ \\
\hline 3 & $\begin{array}{l}\mathrm{MJT} / \mathrm{F5} / \mathrm{I} 53 \\
\mathrm{MJT} / \mathrm{F} 4 / 6 / 20 \\
\mathrm{MJT} / \mathrm{F} 4 / 6 / 17 \mathrm{~B}\end{array}$ & $\begin{array}{l}12 \mathrm{~F}, 8 \mathrm{H} \\
\mathrm{I} 2 \mathrm{Y}, \mathrm{IIH} \\
12 \mathrm{Y}, 8 \mathrm{H}\end{array}$ & $\begin{array}{r}0.07 \\
<0.01 \\
0.09\end{array}$ & $\begin{array}{l}\text { VS } \\
\text { VS } \\
\text { VS }\end{array}$ \\
\hline $4 i$ & $\begin{array}{l}\mathrm{MJT} / \mathrm{F} 5 / 239 \\
\mathrm{MJT} / \mathrm{F} 5 / 56 \\
\mathrm{MJT} / \mathrm{F} 5 / \mathrm{I} 99 \mathrm{~A} \\
\mathrm{MJT} / \mathrm{F} 4 / \mathrm{I} / 5\end{array}$ & $\begin{array}{l}15 \mathrm{~F}, 8 \mathrm{Y} \\
12 \mathrm{~F}, 13 \mathrm{H} \\
1 \mathrm{IF}, 15 \mathrm{H} \\
4 \mathrm{Y}, \mathrm{I} 5 \mathrm{H}\end{array}$ & $\begin{array}{l}0.02 \\
0.06 \\
0.06 \\
0.07\end{array}$ & $\begin{array}{l}\text { VS } \\
\text { VS } \\
\text { VS } \\
\text { VS }\end{array}$ \\
\hline 更 & $\begin{array}{l}\mathrm{MJT} / \mathrm{F} 5 / \mathrm{I} 22 \\
\mathrm{MJT} / \mathrm{F} 5 / \mathrm{I} \text { I I } \\
\mathrm{MJT} / \mathrm{F} 5 / \mathrm{I} 39 \\
\mathrm{MJT} / \mathrm{F} 5 / 89 \\
\mathrm{MJT} / \mathrm{F} 5 / 284 \\
\mathrm{MJT} / \mathrm{F} 5 / 222 \mathrm{~A} \\
\mathrm{MJT} / \mathrm{F} 4 / 5 / 7 \\
\mathrm{MJT} / \mathrm{F} 4 / 8 / 4 \mathrm{~B} \\
\mathrm{MJT} / \mathrm{F} 4 / 5 / 2 \\
\mathrm{MJT} / \mathrm{F} 4 / 2 \mathrm{I} / 5 \\
\mathrm{MJT} / \mathrm{F} 4 / 17 / 7 \\
\mathrm{MJT} / \mathrm{F} 4 / 2 / 6 \mathrm{~A}\end{array}$ & $\begin{array}{l}2 \mathrm{~F}, 4 \mathrm{Y} \\
2 \mathrm{~F}, 5 \mathrm{Y} \\
1 \mathrm{~F} \\
2 \mathrm{~F}, 5 \mathrm{H} \\
3 \mathrm{~F}, 3 \mathrm{H} \\
8 \mathrm{~F} \\
2 \mathrm{Y} \\
4 \mathrm{Y} \\
-\mathrm{Y} \\
-\mathrm{Y} \\
6 \mathrm{Y} \\
-\mathrm{Y}\end{array}$ & $\begin{array}{r}5 \\
4 \\
40 \\
4 \\
5 \\
4 \\
5 \\
5 \\
4 \\
8 \\
4 \\
>\quad 100\end{array}$ & $\begin{array}{l}\text { I } \\
\text { I } \\
\text { R } \\
\text { I } \\
\text { I } \\
\text { I } \\
\text { I } \\
\text { I } \\
\text { I } \\
\text { I } \\
\text { I } \\
\text { R }\end{array}$ \\
\hline $4 \mathrm{iii}$ & $\begin{array}{l}\mathrm{MJT} / \mathrm{F} 5 / \mathrm{I} 4 \\
\mathrm{MJT} / \mathrm{F} 5 / 5 \\
\text { Mima } 5936 \\
\text { Mima Z } 2 \\
\mathrm{MJT} / \mathrm{F} 5 / 96\end{array}$ & $\begin{array}{l}-\mathrm{F},-\mathrm{H} \\
-\mathrm{F},-\mathrm{H} \\
-\mathrm{F},-\mathrm{H} \\
-\mathrm{F},-\mathrm{H} \\
-\mathrm{F},-\mathrm{H}\end{array}$ & $\begin{array}{r}70 \\
30 \\
5 \\
20 \\
>\quad 100\end{array}$ & $\begin{array}{l}\mathrm{R} \\
\mathrm{R} \\
\mathrm{I} \\
\mathrm{R} \\
\mathrm{R}\end{array}$ \\
\hline $\begin{array}{l}4 \text { (ungrouped) } \\
5\end{array}$ & $\begin{array}{l}\mathrm{MJT} / \mathrm{F} 5 / \mathrm{I} 95 \\
\mathrm{MJT} / \mathrm{F} 5 / \mathrm{I} 30 \\
\mathrm{MJT} / \mathrm{F} 4 / 8 / 3 \\
\mathrm{MJT} / \mathrm{F} 4 / 2 \mathrm{I} / 9 \\
\mathrm{MJT} / \mathrm{F} 4 / 18 / 30 \\
\mathrm{MJT} / \mathrm{F} 4 / 3 / \mathrm{I} 6 \\
\text { M. lwoff } \mathrm{NCTC} 5867 \\
\text { M. lwoffi } 950 / 56 \\
\text { Alc. viscosus } \mathrm{NCIB} 8596 \\
\text { Alc. faecalis } \mathrm{NCTC} 8764\end{array}$ & $\begin{array}{l}\text { I IF, IOH } \\
\text { IF } \\
9 \mathrm{Y}, \text { I } 4 \mathrm{H} \\
-\mathrm{Y},-\mathrm{H} \\
-\mathrm{Y},-\mathrm{H} \\
-\mathrm{Y},-\mathrm{H} \\
-\mathrm{F}, 2 \mathrm{H} \\
-\mathrm{F}, 3 \mathrm{H} \\
-\mathrm{F}, 2 \mathrm{H} \\
-\mathrm{F},-\mathrm{H}\end{array}$ & $\begin{array}{c}0.05 \\
7 \\
0.03 \\
10 \\
20 \\
10 \\
14 \\
3 \\
3 \\
>100\end{array}$ & $\begin{array}{l}\text { VS } \\
\text { I } \\
\text { VS } \\
\text { R } \\
\text { R } \\
\text { R } \\
\text { R } \\
\text { I } \\
\text { I } \\
\text { R }\end{array}$ \\
\hline
\end{tabular}

* Radial distance from edge of pellet to edge of inhibition zone, on different media: F, FA; Y, YEA; H, HIA.

$\dagger$ m.i.c. $=$ minimum inhibitory concentration, approximate value.

$\ddagger$ m.i.c. < o.I i.u./ml., VS (very sensitive); 3-9 i.u./ml., I (intermediate); $\geqslant$ Io i.u./ml., R (resistant). 
Phenons 3, 4i, and the ungrouped part of Phenon 4 were very sensitive, with values for m.i.c. of $<0 . \mathrm{I}$ i.u./ml. and zone sizes (with one exception) of $8 \mathrm{~mm}$. or more, whichever basal medium was used. Among the other strains the values of m.i.c. ranged from 3 to $>$ IOO i.u./ml., forming a continuous series. If these latter strains are classed as 'intermediate' or 'resistant' as indicated in Table I2, most intermediate strains gave small zones with 2.5 i.u. tablets, although some showed no zones, or variable results on different media. Nearly all resistant strains produced no zones. Most of the strains tested in Phenon 4ii were intermediate, with two exceptions which were resistant, while strains in Phenon 4 iii were resistant except for one intermediate strain.

In practice, therefore, the test for sensitivity with $2 \cdot 5$ i.u. tablets (Shewan et al. I954) reveals all the very sensitive strains and most of the intermediate strains; positive results in this test may be useful for screening unknown Gram-negative isolates, among which penicillin sensitivity is uncommon. For the separation of the phenons found here an additional routine test using a lower concentration of penicillin, which would detect only the very sensitive strains, would be most useful.

\section{DISCUSSION}

\section{Section I. General considerations}

Representative strains of Pseudomonas, Aeromonas, Escherichia, Cellulomonas and Arthrobacter were excluded from the 72.5-phenon and were clearly shown to be not at all closely related to strains inside it. Non-pigmented glucose-oxidizing strains of Pseudomonas had been compared with non-motile coccoid rods from poultry (then called Achromobacter) in an earlier computer study by Thornley (1960 $b$ ), and the two groups were quite distinct. It was therefore not thought necessary to include nonpigmented glucose-oxidizing pseudomonads in the present survey.

The classification of strains grouped within the $72 \cdot 5$-phenon remains to be considered. It must be remembered, however, that this phenon is not necessarily a taxonomic group, since strains within it may be more closely related to strains not studied in this survey than to other strains within the phenon. For instance, Agrobacterium strains grouped in Phenon I may well be closer to strains of Rhizobium, as would be suggested by the classification of Bergey's Manual (1957), than they are to strains in Phenons 2-5.

One of the most striking findings of this survey has been the separation of motile and non-motile strains into different phenons. Motile, Gram-negative rod-shaped bacteria were grouped into Phenons I and 5, or remained ungrouped, while non-motile Gram-negative or Gram-variable coccoid rods, cocci or short rods were grouped in Phenons 2, 3 and 4. Since the morphological features just mentioned formed only a small proportion of the information used by the computer, it follows that the phenons were also differentiated by other correlated characters such as those shown in Table 10.

The measurements of DNA composition by Mandel \& Thornley (to be published) emphasized this distinction. The 46 strains studied in Phenons 2, 3 and 4 contained between 37 and 46 moles \% guanine plus cytosine (GC) (Table I I). Twelve motile rodshaped strains in Phenons I and 5, and motile Achromobacter strains $(7,8)$ had values ranging from 56 to 67 moles $\%$ GC. 
In view of these facts, it seems desirable that strains in Phenons 2, 3 and 4 should be separated, in the scheme of classification to be adopted, from the motile strains in Phenons I, 5 and ungrouped within the 72.5-phenon. Since representatives of Alcaligenes occur in Phenons 4 and 5, and Achromobacter strains occur in Phenons I-4 and ungrouped within the $72 \cdot 5$-phenon, this entails division of the genera Alcaligenes and Achromobacter. Since both have motile type species, the generic names should be retained for the motile part of each genus (Discussion, 3.I; 3.3).

\section{Section 2. Strains in Phenons 2, 3 and 4: the genus Acinetobacter}

\subsection{The taxonomic position}

In view of the suggested generic division of the strains grouped in Phenons 2, 3 and 4 from those in Phenons $I$ or 5 , it would be logical, on the computer results only, to divide strains in Phenons 2, 3 and 4 into three distinct genera also. This is because the mean similarities between Phenons 2 and 3,3 and 4, and 4 and 5 are very similar, when both computations are considered (Table 5), and this would suggest that each of these phenons should be given the same taxonomic rank. However, the author feels very doubtful about the validity of such a division, for several reasons.

From the computer results, when the characters separating phenons are examined carefully, it appears that Phenons 2 and 3 were separated from Phenon 4 mainly by the fact that strains in these two phenons oxidized five sugars (glucose, galactose, arabinose, xylose, lactose) while strains in Phenon 4 did not. This can be seen from Table II. In the characters most useful for differentiating phenons, only sugar oxidation separated Phenon 3 and 4 i. Penicillin sensitivity and DNA composition also showed marked similarity in these two phenons. Phenon 2 differed from 4 ii and 4 iii in sugar oxidation, and also an ability to grow in citrate medium and resistance to 2.5 i.u. of penicillin. In the latter two characters, it was closer to 4 iii than to 4 ii. It seems likely that the use of sugar oxidation as one feature in the original data would have resulted in strains now grouped in Phenons 2 and 3 being merged with strains in Phenon 4.

In the absence of biochemical evidence about the metabolism of sugars by the poultry isolates, it is impossible to guess whether a computer coding of one feature, five features, or some number in between would best represent the enzyme systems involved in acid production from these sugars. From the very high correlation of positive results for all five sugars, one would suspect that their metabolism is similar and therefore it would be undesirable to regard oxidation of the five sugars as five independent characters suitable for making the main basis of generic separations between Phenons 2, 3 and 4 .

The values for DNA composition, mentioned earlier, support the idea that strains in Phenons 2, 3 and 4 may be more closely related to each other than they are to strains in Phenons I and 5.

It is suggested, therefore, that Phenons 2, 3 and 4 should be regarded provisionally as belonging to the same genus.

\subsection{Nomenclature and definition of the genus}

The correct generic name depends on the names of strains included in the three phenons, and their validity and order of publication. As already mentioned, both Alcaligenes and Achromobacter may be excluded from consideration. 
Neisseria (Trevisan, 1885) is the oldest generic name. However, the one strain of Neisseria studied ( $N$. catarrhalis, NCTC 3622) did not grow in some of the tests used, and therefore its inclusion in Phenon 4 is not well established. Besides this fact, the genus Neisseria consists entirely of coccoid cells, and therefore does not seem appropriate for a collection of strains ranging from cocci to short rods.

The name Diplococcus mucosus of von Lingelsheim (1906, 1908) is probably not appropriate for the strains in Phenon 2 (Discussion, 2.3); in any case, Diplococcus cannot be used as a generic name for this group because it is now regarded as a genus of the Tribe Streptococceae (Bergey's Manual, 1957).

Mima was mentioned as a genus of the Tribe Mimeae described by De Bord (1939); in 1942 Herellea was named by De Bord as another genus of Mimeae, and some further particulars were given. Henriksen (I963) discussed the inadequacy of the descriptions of both genera and various reasons why the names Herellea and Mima polymorpha var. oxydans should be considered illegitimate. He recommended that the specific epithet 'Iwoffi', from Audureau's (1940) description of Moraxella lwoffi, should be conserved against 'polymorpha'; if it is decided to do this, the genus Mima will cease to exist. The present author considers that, in view of the lack of details in De Bord's descriptions, this would be the most satisfactory course.

Moraxella was proposed by Lwoff (1939) as a new genus for bacteria previously included in Haemophilus but not requiring $\mathrm{X}$ or $\mathrm{V}$ factors for growth. Moraxella lacunata, the Morax-Axenfeld bacillus, was the type species and needed unidentified growth factors present in serum, while $M$. duplex, with three varieties, would grow in peptone water. Later, additional species were proposed. Audureau (1940) described strains which would grow in an inorganic medium containing citrate and ethanol, and called these $M$. lwoffi. Four strains of $M$. lwoffi were included in Phenon 4 in the present survey. Moraxella lwoffi var. glucidolytica was described by Piéchaud \& Second (195I) and later given specific rank as M. glucidolytica (Piéchaud et al. 1956). This species differed from $M$. lwoffi in producing acid from various sugars, and strains with properties similar to those described for $M$. glucidolytica were grouped in Phenon 2 in the present survey. If the classification of $M$. lwoffi and $M$. glucidolytica (or anitrata) in the same genus as $M$. lacunata and $M$. duplex be accepted, it would appear that Moraxella is the correct name for all strains in Phenons 2, 3 and 4 .

However, this is the subject of controversy. The species mentioned above are similar in morphology (Murray \& Truant, 1954), even when this is investigated in detail by electron microscopy (Ryter \& Piéchaud, 1963). Besides the authors mentioned, Lwoff (I964) advocates inclusion of all these species in Moraxella, mainly for morphological reasons and also because of the observation of gliding motility in members of most of these species (Piéchaud, I963).

Henriksen (I952) showed that the alleged Moraxella species could be divided into two groups on various properties; the species originally proposed by Lwoff being oxidase-positive and penicillin-sensitive, while $M$. lwoffi and $M$. glucidolytica (or anitrata) were oxidase-negative and penicillin-resistant. Henriksen concluded that the two latter should be excluded from Moraxella, and later (Henriksen, 1960) supported their classification as Acinetobacter lwoffi and A. anitratum by Brisou \& Prévot (1954) and Brisou (1957). Steel \& Cowan (1964) also favoured this solution, and pointed out that $A$. lwoffi and $A$. anitratus would be more correct forms of the names; their recommendations were followed by Pintér \& Bende (1967). The present 
study gives no direct evidence on this problem, because no strains of the oxidasepositive Moraxella species were included. It does, however, show that both oxidasepositive penicillin-sensitive strains and those with the converse properties, can be closely related, and therefore that these characters are not necessarily good ones for making generic divisions in this group of bacteria.

In the absence of direct evidence on the relationship between the bacteria studied here and Moraxella lacunata, it is suggested that the genus Acinetobacter of Brisou \& Prévot (I954) should be used for the provisional classification of the bacteria of Phenons 2, 3 and 4. This would agree with the views of Henriksen (I960) and Steel \& Cowan (1964) for 'anitratum' and ' $w$ offi'. In addition to these species, which occur in Phenons 2 and 4, Brisou \& Prévot placed Achromobacter lacticum (Phenon 2) and Alcaligenes viscosus (Phenon 4) in Acinetobacter. Their definition of the genus does not exclude any of the strains of Phenons 2, 3 and 4, and they mention 'short, coccoid forms are frequent', which fits the morphological properties of these phenons. In the amended definition of Acinetohacter by Steel \& Cowan (1964), the character 'oxidase-negative' is added. This would have to be deleted to allow the inclusion of the strains of Phenons 3 and 4 . Their addition of the property 'sugars oxidised or not attacked at all' is confirmed. The present study shows also that the arginine test was always negative in Phenons 2, 3 and 4 (Table II).

The following revised definition is therefore suggested: Acinetobacter Brisou \& Prévot.

Gram-negative or Gram-variable, non-motile coccoid rods, short rods or cocci, often in pairs; able to grow aerobically on ordinary nutrient media without the addition of serum; colonies whitish or cream, producing no fluorescent pigment; catalase-positive; sugars oxidised or not attacked at all; arginine test negative.

The DNA composition found for 46 strains of Acinetobacter by Mandel \& Thornley (to be published) ranged from 36 to 47 moles \% GC.

Properties which varied among phenons included in Acinetobacter are listed in Table I I.

\subsection{The type species, Acinetobacter anitratus, as represented by the strains in Phenon 2}

The type species was designated Acinetobacter anitratus by Brisou (1957) and Steel \& Cowan (1964). This species was originally described as Bacterium anitratum by Schaub \& Hauber (1948) and Ferguson \& Roberts (1950), and the latter authors also showed its identity with strains called B5W by Stuart, Formal \& McGann (1949). Authentic strains used by all three authors (strains I, 32-39 in Table I) were included in the present survey, and were grouped in Phenon 2, together with one strain (strain 13 , NCIB 9019) isolated by Brisou (1957) (Table 6).

As this phenon had a mean similarity of $84 \%$ and showed no signs of heterogeneity (Fig. I), it is suggested that strains within the phenon should be regarded as representatives of the same species. This is supported by the fact that a comparable mean similarity value of $87 \%$ was found by Pinter \& Bende (1967) for eight strains of Acinetobacter anitratus, most of which were originally identified by the criteria of Cowan \& Steel (I965) as belonging to the same species. 


\subsection{Nomenclature of the type species}

Besides strains originally called Bacterium anitratum, Phenon 2 included strains called Achromobacter lacticum, Herellea, Diplococcus mucosus and Moraxella lwoffi. Many previous authors have studied resemblances between strains with these names (except Achromobacter lacticum), and have indicated that some of them are synonyms. As the nomenclature of this group is confused, an account of the origins of the earlier names is given below. Comparative studies showing relationships between strains with these names (or between the definitions of the taxonomic groups) are listed in Table I3. As far as can be checked from descriptions, the work listed all relates to strains with the properties of Phenon 2.

Bacterium anitratum was well described in the early work mentioned above, and as original cultures have been preserved, the identity of new isolates with this species can be satisfactorily established. Unfortunately the generic name 'Bacterium' is invalid, but the specific name 'anitratum' has been retained by many authors, and used in combination with Achromobacter, Acinetobacter or Moraxella (see Table I3). Henriksen (1963) considers that 'anitratum' is the correct specific name, whatever generic name is finally adopted.

Moraxella lwoffi var. glucidolytica (or $M$. glucidolytica) was well described in the original studies of Piéchaud et al. (I95I), which were amplified by Piéchaud et al. (I956). There is no doubt that the organisms they studied correspond in properties to organisms described as Bacterium anitratum; this has been shown by many comparative studies (Table I3).

Diplococcus mucosus was described by von Lingelsheim (1906, I908) as a capsulated, Gram-negative coccus occurring in pairs or tetrads. None of his cultures is now available. Since that time, the name has been applied to strains with differing properties. The authors listed in Table $\mathrm{I} 3$ in reference to this organism, and the present author, studied strains previously identified as Diplococcus mucosus, but with properties similar to those of Bacterium anitratum. Seeliger (1952/53) considered that D. mucosus was the correct name for these organisms, and Achromobacter mucosus (von Lingelsheim, I906) was used by Stenzel and Mannheim (1963) to designate a group of their own isolates with properties similar to B. anitratum. On the other hand, Cowan (I938) described isolates which resembled those of von Lingelsheim and which differed from $B$. anitratum in several respects, including the reduction of nitrates. Cowan considered that these organisms should be classified as Neisseria mucosa. Véron, Thibault \& Second (1959) studied strains which resembled those of Cowan in reducing nitrate, but differed in other respects. They were cocci forming pairs and tetrads, were oxidasepositive and differed in sugar reactions and other properties from B. anitratum. Véron, Thibault \& Second called them Neisseria mucosa, and later showed their serological relationship with strains of Neisseria sicca, but not with other species of Neisseria or with $B$. anitratum (Véron, Thibault \& Second, 196I). It appears therefore that 'mucosus' is not a suitable specific name for strains in Phenon 2.

Herellea was described by De Bord $(1939,1942)$ as a genus in the new tribe Mimeae together with the genera Mima and Colloides. No original strains are available. It was soon established that strains identified as Herellea by Deacon (1945) were similar in morphology and were serologically related to authentic strains of Bacterium anitratum (Ewing, 1949). Strains designated 'Herellea-like' by Aiken, Ward \& King (1956) 


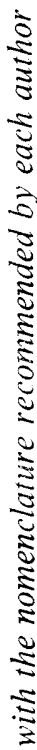

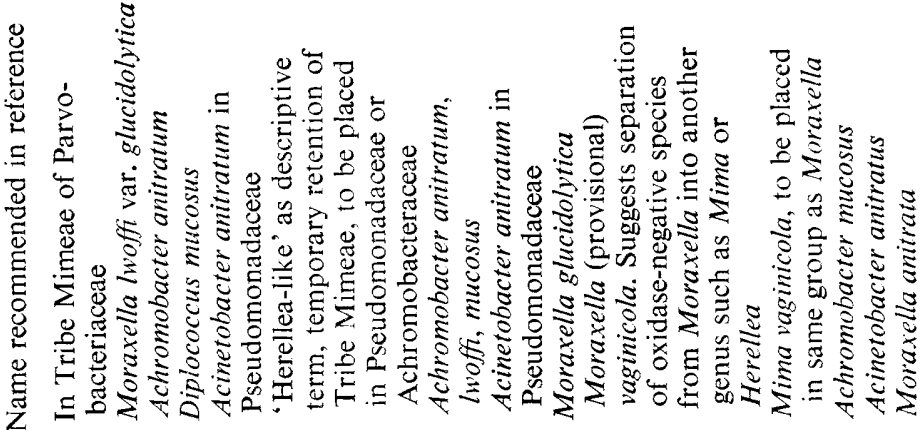

吾

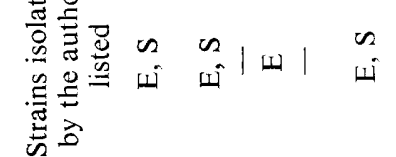

| | 山س

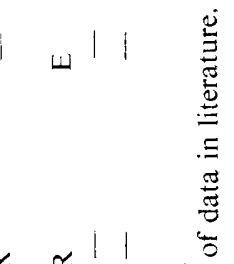

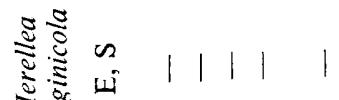

| 1 州

$\simeq \simeq 1$

i

కับ

芯悹

山 |

| $1 \mid$ ह 일

2.5

ㄱ.

$\stackrel{5}{\frac{0}{5}}$

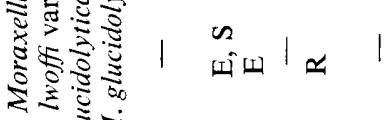

Ш $\simeq$ 니

$\simeq \simeq \simeq \simeq$

造密

a

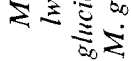

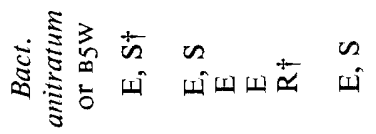

山 $\simeq \simeq$

$\simeq \simeq \simeq \simeq$
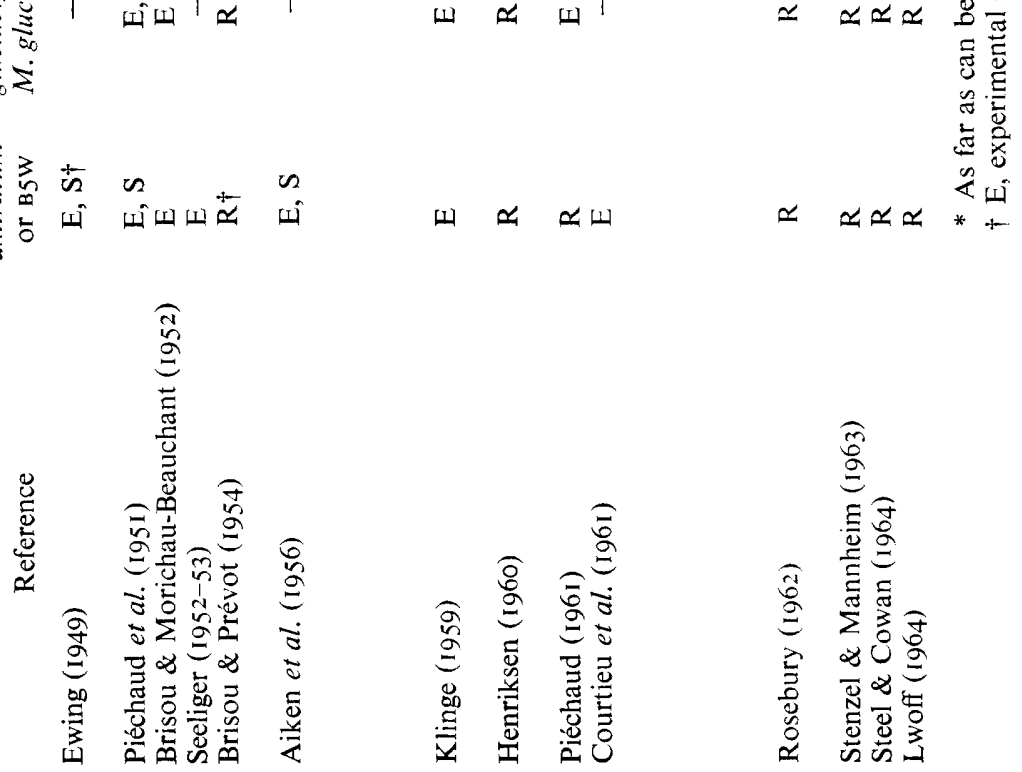

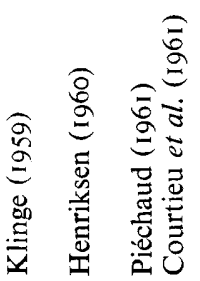

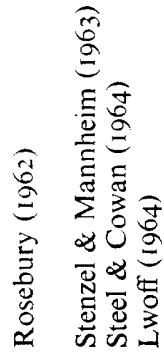


were also biochemically and serologically similar to $B$. anitratum. Courtieu, Chassignol \& Longeray (196I) and the present author included strains of Herellea obtained from Dr E. O. King in comparative surveys. Both studies confirmed that these strains possessed the properties of $B$. anitratum. However, Henriksen (1963) pointed out differences between the descriptions of Herellea given by De Bord (1942) and those of Deacon (I945) and later workers. Among several discrepancies, the fermentation of mannitol and dulcitol by De Bord's strains and no fermentation in Deacon's strains was one of the most important differences. Henriksen considered that the name Herellea was not applicable to strains, like those of Deacon, with the properties of $B$. anitratum, and that since strains corresponding to Herellea did not seem to be recognizable, this name should be rejected as a nomen dubium.

\subsubsection{Evidence from the present work}

The present study confirms earlier evidence (Table 13) that the same properties are shared by strains called Bacterium (or Achromobacter or Acinetobacter) anitratum, Moraxella lwoff var. glucidolytica (or Moraxella glucidolytica), Herellea and Diplococcus mucosus. These species were all isolated from human sources, usually from pathological material but sometimes from healthy individuals (see Rosebury, 1962). A few cases of the isolation of similar organisms from saprophytic sites are quoted by Rosebury, including Billing's (I955) description of soap-tolerant strains (Achromobacter anitratum var. saponiphilum) from face-flannels and sponges.

The present investigation showed for the first time that strains from slimy milk, called Achromobacter lacticum and agreeing with the description of this organism in Bergey's Manual (1939, p. 519), were also indistinguishable from Bacterium anitratum. One of these strains, $\mathrm{NCIB} 8208$, was the second highest in order of mean similarity to the other strains in Phenon 2, with a value of $88.0 \%$ (Table 6 ). The highest mean similarity value, $88.5 \%$, was shown by $B$. anitratum B25 (B5W99), one of Ferguson \& Roberts' (I950) strains. The positions of NCIB 8208 and NCIB 8209 in Table 6 indicate that both these strains had properties typical of Phenon 2.

Of the I Io poultry isolates studied, only one strain (MJT/F5/2II) fell into Phenon 2, to which its mean similarity was low (Table 6); its properties were not typical of the phenon, as it reduced nitrate and was sensitive to penicillin. Gardner (1965) studied the microflora of fresh meat, and of $9 \mathrm{I}$ isolates called Achromobacter which were similar in general properties to the poultry isolates, only one strain had properties similar to those of Phenon 2.

\subsection{Phenons included in Acinetobacter but not regarded as species}

The close resemblance between strains in Phenon 3 and those of Phenon $4 \mathrm{i}$ (Discussion, 2.1) suggests that it would be premature to assign specific status to Phenons 3 and 4 , since the study of additional characters might in future cause the rearrangement of these phenons.

\subsection{Phenon 3}

This contains only poultry isolates and one strain from fish. No strains of human origin with the same properties (Table II) have been described. Perhaps the closest resemblance is to Moraxella saccharolytica, described by Flamm (I956) on the basis of one strain, and discussed by Henriksen (I960). This strain had the morphological 
properties typical of a Moraxella, was oxidase-positive, penicillin-sensitive and decomposed some sugars to acid products. However, it was resistant to tetracyclines, while the strains in Phenon 3 were sensitive to terramycin (oxytetracycline).

Among bacteria of non-medical significance, strains with similar morphological properties were mentioned by Shewan et al. (1960). These were penicillin-sensitive and either oxidized or did not attack glucose in the Hugh \& Leifson test. The oxidase test was not applied to these strains, but a similar group was described as oxidasepositive by Hendrie et al. (1964); as one of Dr Shewan's strains was included in Phenon 3, there is little doubt that his glucose-oxidizing strains are similar to the poultry isolates of Phenon 3. Shewan et al. (1960) included this group in Achromobacter, and Hendrie et al. (1964) retained this term, but suggested that the genus Acinetobacter of Brisou \& Prévot (1954) might be appropriate.

Among the 9I strains from fresh meat identified as Achromobacter, Gardner (1965) found four strains which were oxidase-positive, sensitive to $2.5 \mathrm{i}$.u. penicillin and oxidized glucose in the Hugh \& Leifson test. As far as they have been described, these were similar to the poultry isolates of Phenon 3.

\subsubsection{Phenon 4}

This contained 93 poultry isolates and 77 named strains including Mima, Moraxella, Alcaligenes viscosus and (possibly) Neisseria catarrhalis, and the properties found within the phenon and its subdivisions are listed in Table I I.

Phenon 4i contained an oxidase-positive strain of Mima, strain $\mathrm{Z4}$. It has been stated (Henriksen, I952; Murray \& Truant, I954) that Mima polymorpha var. oxidans is indistinguishable from Moraxella duplex var. nonliquefaciens, and Catlin \& Cunningham (1964b) showed transformation between strains with these two names. It appears therefore that Phenon $4 \mathrm{i}$ may be similar to the latter organism. Besides the oxidase-positive nature of the strains, their very high penicillin-sensitivity fits in with the results of Henriksen (I952) for this species.

Phenon 4 ii contained no named strains.

The significance of Phenon 4 iii is not clear, as it was a very small group (seven strains), did not appear in the second computation, and contained two sets of strains with significantly different GC content of the DNA, which was 37-40 moles \% for the four poultry strains and $44-45 \%$ for three Mima strains (Mandel \& Thornley, to be published).

The portion of Phenon 4 which remained ungrouped into smaller phenons consisted of $27 \%$ of the poultry isolates and $59 \%$ of the named strains. Their failure to fall into the small groups was due to the possession of different combinations of the properties shown in Table $\mathrm{I}$, but in general the correlation between results in the oxidase test and reduction of nitrate shown in Phenons 2, 3, 4i , 4ii and 4 iii held good for most of the ungrouped strains also. Only i $\%$ of the poultry isolates and 4 of the 17 named strains in Phenon 4 did not show this correlation.

Although the oxidase test is useful for differentiation of genera among other groups of bacteria, this does not seem to apply here, because Phenons $4 \mathrm{i}$ and $4 \mathrm{ii}$, which differed in this character, were linked at $90 \%$ similarity. This seems much too close for division into different genera.

The synonymity between certain species of Moraxella and Mima was first noted in connection with the oxidase-positive strains already mentioned. From the investi- 
gations listed in Table 13 , which showed the similarity of strains previously identified as Moraxella glucidolytica to those identified as Herellea, it followed that strains called Moraxella lwoffi should be identical with oxidase-negative strains of Mima polymorpha, since both had already been shown to resemble the sugar-oxidizing strains in all but sugar reactions (Piéchaud et al. 195 I; Aiken et al. 1956).

The present study shows that isolates received as Moraxella lwoffi were closely related to those received as Mima, since all were included in Phenon 4. Apart from the oxidase-positive Mima $\mathrm{z}_{4}$, six oxidase-negative strains called Mima and four called Moraxella lwoffi were studied, and considerable variation in properties was found among these ten strains. Pintér \& Bende (I967) studied a group of 3I strains of Acinetobacter lwoff, including 28 of their own isolates and NCTC 5866 (strain 63 of the present work); the 3I strains formed a closely related group with a mean similarity of $82 \%$. The properties of these strains were not quoted, but in the present work, NCTC 5866 formed part of the group of three strains of Moraxella lwoffi, for which properties are given in Table I I. A further comparison of more human isolates with poultry strains would be useful to show whether this very small group represents a large proportion of strains of $M$. lwoffi, and whether these would form a group distinct from the groups of poultry isolates.

Neisseria catarrhalis NCTC 3622 was also placed in Phenon 4 , but this was not very well established, because of its failure to grow in some tests. Nevertheless, a relationship with strains similar to Moraxella would not be surprising in view of Catlin's (1964) observation of transformation between $N$. catarrhalis and $M$. nonliquefaciens. The DNA of seven strains of $N$. catarrhalis contained between 4 I and 44.5 moles $\%$ GC (Catlin \& Cunningham, I964a), a value within the range shown by Phenon 4 (Mandel \& Thornley, to be published; Table I I). The observation of division into tetrads by one of the poultry isolates (Pl. 2, fig. 6) is a property previously thought to be characteristic of Neisseria (Murray \& Truant, I954; Piéchaud, 1961).

The similarity of Alcaligenes viscosus to Moraxella lwoffi was noted by Brisou \& Prévot (1954), who placed them both in the genus Acinetobacter, and by Billing ( 1955), and is confirmed here by the inclusion of two A. viscosus strains in Phenon 4.

Bacteria which were morphologically similar to strains in Phenon 4 have been described as occurring on poultry, meat and fish, particularly during aerobic storage at low temperatures; several references are quoted in the Introduction, and all the authors called these isolates either Achromobacter, Alcaligenes or AchromobacterAlcaligenes group. Buttiaux (196I) described Achromobacter strains as non-motile coccoid rods which did not produce acid from sugars and might be oxidase-positive or oxidase-negative; these are probably similar to the poultry isolates of Phenon 4. Buttiaux suggested a future generic separation of oxidase-positive from oxidasenegative strains, but the present results do not support such a separation.

Sulzbacher (1950) described isolates from frozen pork, some of which were nonmotile very short oval rods, probably belonging to Achromobacter; one of his isolates (Achromobacter 25A2, strain I2) was included in Phenon 4 of the present survey. The strains of non-motile Achromobacter (or Acinetobacter) of Hendrie et al. (1964) were described as mostly oxidase-positive, and one of their strains (Achromobacter I3I, strain I0) was placed in Phenon 4. Although both strains, 25A2 and I3I, were found to be oxidase-positive, neither was included in Phenon $4 \mathrm{i}$ as the combination of other properties was not typical of this small phenon (Table II). Of Gardner's (I965) 9I 
isolates of Achromobacter from fresh beef, 83 strains were inert with glucose, so would appear to be similar to Phenon 4 . These 83 strains included both oxidase-positive and oxidase-negative, penicillin-sensitive and penicillin-resistant strains; 4I strains were oxidase-positive and penicillin-sensitive.

It is clear that isolates from a wide variety of protein foods are similar to the bacteria included in Phenon 4.

\subsection{Alcaligenes}

\section{Section 3. Other genera represented in the survey}

Of the strains received as Alcaligenes, two non-motile oxidase-negative strains of Alcaligenes viscosus (NCIB 8154, NCIB 8596) were included in Phenon 4 and have been dealt with as Acinetobacter. The other eight strains were all oxidase-positive and motile under suitable conditions, and included two strains with polar flagella and five with peritrichous flagella (Results, 2.2.1.1).

Alcaligenes faecalis, the type species, is described as peritrichously flagellate, and two named strains of this species $(21$, NCTC $655 ; 20$, NCTC 8764$)$ had this property and were grouped with four other strains (of which three had peritrichous flagella) in an $87 \cdot 5$-phenon. This included two strains from soil $(29,30)$ which were closely related to the rest of the phenon, and strain 25, NCTC 8582 , the type species of $A$. denitrificans. This species was separated from A. faecalis by Leifson \& Hugh (1954) on the basis of gas production from nitrate, but the close relationship shown here (Fig. 5) provides no evidence to support species separation. Strain 26, NCTC 3233 , may have been originally mistakenly identified as $A$. viscosus; the two other strains of this name (NCIB 8154, NCIB 8596) which were included in Phenon 4 corresponded more closely to the descriptions of the species by Long \& Hammer (1936) and Abd-el-Malek \& Gibson (1952). The strain Achromobacter sp. NCIB 9650, studied after the computing was done, was also very similar to several strains in the 87.5 -phenon, and should be classified as an Alcaligenes.

The properties of the six strains in the $87 \cdot 5$-phenon agreed with those described for Alcaligenes faecalis in Bergey's Manual (1957), and in addition, they were oxidasepositive and citrate-positive, as quoted by Thibault (196r) for peritrichously flagellate strains. These properties are included in the results for the whole of Phenon 5 listed in Table 10. However, a more extensive study of strains of A. faecalis is reported by Board (1965).

Both polarly flagellate strains (22 Alcaligenes faecalis NCTC $8769 ; 24$ A. bookeri NCIB 8155) showed several resemblances, including the late positive result in arginine, to Hugh \& Ikari's (1964) neotype strain of Pseudomonas alcaligenes (ATCC 14909, NCTC I0367). However, the DNA composition of strains 22 and 24 was $62-63$ moles \% GC (Mandel \& Thornley, to be published) while that of ATCC I 4909 was 66 moles \% GC (Mandel, 1966). This suggests that strains 22 and 24 may be more similar to P. pseudoalcaligenes (Stanier, Palleroni \& Doudoroff, 1966), which contained 63 moles \% CG (Mandel, r966).

The finding of both polarly and peritrichously flagellate strains among bacteria previously identified as Alcaligenes has been reported many times; for instance, by Nyberg (1935), Türck (1952), Moore \& Pickett (I960 $b$ ) and Thibault (I96I). The present work indicates a few differences in biochemical properties between the two groups (Results, 2.2.I.2), but many more could probably be found by the application 
of tests characteristic of Pseudomonas alcaligenes and pseudoalcaligenes (Stanier et al. 1966) and of Alcaligenes faecalis (Board, 1965).

Several authors have recommended that the genus Alcaligenes should be abandoned, and that strains formerly called Alcaligenes should be placed in Achromobacter. Brisou \& Prévot (1954) separated non-motile strains as Acinetobacter, and motile strains, including both polarly and peritrichously flagellate types, were regarded as Achromobacter. Hendrie et al. (1964) agreed with the abolition of Alcaligenes, and the separation of non-motile strains, but would include only peritrichous strains in Achromobacter. Moore \& Pickett (1960 $a, b$ ) wished to abolish Alcaligenes and include both non-motile and peritrichous strains of Achromobacter. The results of the present work showed the existence of a well-defined group of six strains with the properties of Alcaligenes faecalis, including peritrichous flagellation. Since this is the type species of Alcaligenes, the position of this genus seems much more satisfactory than that of Achromobacter, in which the existence of the type species is still doubtful. The retention of the genus Alcaligenes for strains resembling A. faecalis therefore seems desirable.

\subsection{Agrobacterium}

Only three named strains of Agrobacterium were included in the survey, and these were grouped in Phenon I together with strain 2, Achromobacter hartlebii NCIB 8I 29. This suggests that strain 2 should be considered for possible inclusion in Agrobacterium.

In the present survey, the oxidative production of acid from sucrose and fructose, and the formation of $\mathrm{H}_{2} \mathrm{~S}$ in Kliger medium, differentiated Phenon I from all strains in Phenons 2-5, while the positive oxidase test for Phenon I was useful for differentiation from the oxidase-negative groups. However, it is not known whether these properties are widespread among Agrobacterium strains. The 3-ketoglycoside test of Bernaerts \& De Ley ( 1963 ), which is claimed to give positive results only for strains of Agrobacterium, was unfortunately not included in the survey, as the tests were completed before its publication.

\subsection{Achromobacter}

Most of the strains received as Achromobacter proved to be non-motile coccoid rods, which were grouped in Phenons 2, 3 and 4, and have been placed provisionally in the genus Acinetobacter.

Of the strains found to be motile, Achromobacter hartlebii NCIB 8I29 was included in Phenon 1, and may be suitable for classification as Agrobacterium (Discussion, 3.2).

The two soil strains isolated by Dr A. J. Holding differed, Achromobacter CB I I (strain 7) being much like Phenon I and Achromobacter 7AI4 (strain 8) being equally similar to Phenons I and 5 (Table 8, Results 2.2.2.). These strains could be considered as motile Achromobacters, but the resemblance to Phenon I emphasizes the need to establish whether any major differences exist between Agrobacterium strains and motile glucose-oxidizing strains classified as Achromobacter. Of the differential characters used by Holding (I960), only a growth requirement for organic nitrogen separated the two groups, strains with this requirement being placed in Achromobacter.

The strain isolated by Tulecke et al. (1965), Achromobacter liquefaciens ATCC I 57 I6, may well be similar to that originally described by Eisenberg (I89I), but its relation to other Gram-negative strains suitable for inclusion in Achromobacter remains to be 
proved; it has many differences from all strains in this survey, and it may be suggested (Results, 2.3) that it is more closely related to some Gram-positive genus.

The existence of a group of motile strains suitable for classification as Achromobacter has therefore not been established, although Holding's two soil strains may be in this category. However, there are further motile strains available in culture collections which were not studied here. Since the types species, A. liquefaciens, is described as motile, it seems best to reserve the genus Achromobacter for any motile strains which may prove to be suitable for inclusion.

The author is indebted to Messrs J. C. Gower and G. S. J. Ross for the computing; to Mr R. W. Horne and Dr A. M. Glauert for electron microscopy; to Dr S. T. Cowan and Dr P. H. A. Sneath for helpful discussions, and to Mrs A. A. Laurie and Miss K. M. Moden for skilled technical assistance.

\section{REIIRENCES}

AbD-el-Malek, Y. \& Gibson, T. (1952). Studies in the bacteriology of milk. IV. The Gram-negative rods of milk J. Dairy Res. 19, 294.

AIKEN, M. A., WARD, M. K. \& KING, E. O. (1956). A study of a group of Gram-negative bacteria resembling the tribe Mimeae (De Bord). The Public Health Laboratory 14, no. 5, I 26.

Audureau, A. (1940). Étude du genre Moravella. Annls Inst. Pasteur, Paris 64, 126.

Ayres, J. C., Ogilvy, W. S. \& Stewart, G. F. (1950), Post mortem changes in stored meats. I. Microorganisms associated with development of slime on eviscerated cut-up poultry. Fd Technol., Champaign 4, 199.

Barnes, E. M. \& Thornley, M. J. (1966). The spoilage flora of eviscerated chickens stored at different temperatures. J. Fd Technol. I, 11 1.

BeERS, R. J. \& LockHART, W. R. (1962). Experimental methods in computer taxonomy. J. gen. Microbiol. 28,633 .

Bergey's Manual of Determinative Bacteriology (1923) ist ed. Ed. by D. H. Bergey, F. C. Harrison, R. S. Breed, B. W. Hammer \& F. M. Huntoon. Baltimore: Williams and Wilkins.

Bergey's Mamual of Determinative Bacteriology (1939). 5th ed. Ed by D. H. Bergey, R. S. Breed, E. G. D. Murray \& A. P. Hitchens. Baltimore: Williams and Wilkins.

Bergey's Manual of Determinative Bacteriology (1957). $7^{\text {th }}$ ed. Ed by R. S. Breed, E. G. D. Murray \& N. R. Smith. London: Baillière, Tindall and Cox.

Bernaerts, M. J. \& De Ley, J. (I963). A biochemical test for crown gall bacteria. Nature, Lond. 197, 406.

BILLING, E. (1955). Studies on a soap tolerant organism: a new variety of Bacterium anitratum. J. gen. Microbiol. $\mathbf{1 3}, 252$.

BOARD, R. G. (1965). The properties and classification of the predominant bacteria in rotten eggs. J. appl. Bact. 28, 437.

Bkisou, J. (1957). Contribution a l'étude de la systématique des Pseudon :nadaceae. Annls Inst. Pasteur, Paris 93, 397.

Brisou, J. \& Morichau-Beauchant, R. (1952). Identité biochimique entre certaines souches de B. anitratum et Moraxella lwoffi. Annls Inst. Pasteur, Paris 82, 640.

Brisou, J. \& Prévot, A-R. (1954). Études de systematique bactérienne X. Révision des espèces réunies dans le genre Achromobacter. Annls Inst. Pasteur, Paris 86, 722.

Buttiaux, R. (196I). Pseudomonas non pigmentés et Achromobacter. Annls Inst. Pasteur, Paris roo, Suppl. to no. 6, 43 .

Castellani, A. \& Chalmers, A. J. (1919). Manual of Tropical Medicine, 3rd ed. London: Baillière, Tindall and Cox.

CATlin, B. W. (1964). Reciprocal genetic transformation between Neisseria catarrhalis and Moraxella nonliquefaciens. J. gen. Microbiol. 37, 369.

Catlin, B. W. \& Cunningham, L. S. (I964a). Genetic transformation of Neisseria catarrhalis by deoxyribonucleate preparations having different average base compositions. J. gen. Microbiol. 37, 341 . 
Catlin, B. W. \& Cunningham, L. S. (1964b). Transforming activities and base composition of deoxyribonucleates from strains of Moraxella and Mima. J. gen. Microbiol. 37, 353.

Clarke, P. H. (I953). Hydrogen sulphide production by bacteria. J. gen. Microbiol. 8, 397.

Courtieu, A-L., Chassignol, S. \& Longeray, C. (196I). Caractères bacteriologiques de 2 I 4 souches de Moraxella lwoffi et de $M$. glucidolytica (Acinetobacter). Annls Inst. Pasteur, Paris roo, Suppl. to no. 6 , II 6 .

Cowan, S. T. (1938). Unusual infections following cerebral operations. With a description of Diplococcus mucosus (von Lingelsheim). Lancet ii, 1052.

CowAN, S. T. \& STEEL, K. J. (I965). Manual for the Identification of Medical Bacteria. Cambridge University Press.

DE Bord, G. G. (I939). Organisms invalidating the diagnosis of gonorrhea by the smear method. J. Bact. 38, I 19.

DE Bord, G. G. (1942). Descriptions of Mimeae trib. nov. with three genera and three species and two new species of Neisseria from conjunctivitis and vaginitis. Iowa St. Coll. J. Sci. x6, $47 \mathrm{I}$.

Deacon, W. E. (1945). A note on the Tribe Mimeae (De Bord). J. Bact. 49, 5 I I.

EDDY, B. P. (1960). Cephalotrichous, fermentative Gram-negative bacteria: the genus Aeromonas. J. appl. Bact. $23,2 \mathrm{I} 6$.

EISENBERG, J. (I89I). Bakteriologische Diagnostik, 3rd ed. Hamburg and Leipzig: Leopold Voss.

Evans, A. C. (19I6). The bacteria of milk freshly drawn from normal udders. J. infect. Dis. r8, 437 .

EwING, W. H. (1949). The relationship of Bacterium anitratum and members of the Tribe Mimeae (De Bord). J. Bact. 57, 659.

Ferguson, W. W. \& Roberts, L. F. (1950). A bacteriological and serological study of organism B 5 W (Bacterium anitratum). J. Bact. 59, I7I.

Flamm, H. (I956). Moraxella saccharolytica (sp. n.) aus dem Liquor eines Kindes mit Meningitis. Zentbl. Bakt. ParasitKde (Abt I. Orig.), 166, 498.

Gardner, G. A. (1965). Microbiological and biochemical changes in fresh meat during storage. Ph.D. thesis, Belfast, Queen's University.

Hendrie, M. S., Hodgkiss, W. \& Shewan, J. M. (1964). Considerations on organisms of the Achromobacter-Alcaligenes group. Annls Inst. Pasteur, Lille 15, 43.

Henriksen, S. D. (1952). Moraxella: classification and taxonomy. J. gen. Microbiol. 6, 3 I 8.

HenRiksen, S. D. (1960). Moraxella. Some problems of taxonomy and nomenclature. Int. Bull. bact. Nomencl. Taxon. ro, 23.

Henriksen, S. D. (1963). Mimeae. The standing in nomenclature of the names of this tribus and of its genera and species. Int. Bull. bact. Nomencl. Taxon. 13, 51.

Hill, L. R., Turri, M., Gilardi, E. \& Silvestri, L. G. (1961). Quantitative methods in the systematics of Actinomycetales II. G. Microbiol. 9, 56.

Holding, A. J. (I960). The properties and classification of the predominant Gram-negative bacteria occurring in soil. J. appl. Bact. 23, 5 I 5 .

HUGH, R. \& IKARI, P. (I964). The proposed neotype strain of Pseudomonas alcaligenes Monias 1928. Int. Bull. bact. Nomencl. Taxon. 14, I03.

Hugh, R. \& Leifson, E. (1953). The taxonomic significance of fermentative versus oxidative metabolism of carbohydrates by various Gram-negative bacteria. J. Bact. 66, 24 .

InGRAM, M. \& SHEwAN, J. M. (1960). Introductory reflections on the Pseudomonas-Achromobacter group. J. appl. Bact. 23, 373 .

KING, E. O., WARD, M. K. \& RANEY, D. E. (1954). Two simple media for the demonstration of pyocyanin and fluorescin. J. Lab. clin. Med. 44, 301 .

KLINGE, K. (1959). Zur Systematik von Bacterium anitratum, Diplococcus mucosus und Moraxella lwoff. Arch. Hyg. Bakt. 143, 587.

Kovacs, N. (1956). Identification of Pseudomonas pyocyanea by the oxidase reaction. Nature, Lond. $\mathbf{1 7}, 703$.

LeIfson, E. \& HUGH, R. (1954). Alcaligenes denitrificans n.sp. J. gen. Microbiol. I1, 5 I 2.

Lemoigne, M., Girard, H. \& Jacobelli, G. (I952). Bactérie du sol utilisant facilement le 2-3 butanediol. Annls Inst. Pasteur, Paris 82, 389. 
Lingelsheim, W. vON (1906). Die bakteriologischen Arbeiten der Kgl. Hygienischen Station zu Benthen O. Schl. während der Genickstarre Epidemie in Oberschlesien im Winter 1904/5. Klin. Jb. 15, 373.

LingelsheIM, W. vON (I908). Beiträge zur Ätiologie der epidemischen Genickstarre nach den Ergebnissen der letzten Jahre. Z. Hyg. Infekt-Krankh. 59, 457.

Long, H. F. \& Hammer, B. W. (I936). Studies on Alcaligenes viscosus. Iowa St. Coll. J. Sci. ro, 26 I.

Lwoff, A. (1939). Revision et démembrement des Haemophilae, le genre Moraxella nov. gen. Annls Inst. Pasteur, Paris 62, 168.

Lwoff, A. (1964). Remarques sur les Moraxella. Annls Inst. Pasteur, Paris ro6, 483.

Mackie, T. J. \& MCCartney, J. E. (1950). Handbook of Practical Bacteriology, 8th ed. Edinburgh: E. and S. Livingstone, Ltd.

Mandel, M. (1966). Deoxyribonucleic acid base composition in the genus Pseudomonas. J. gen. Microbiol. 43, 273.

Moore, H. B. \& Pickett, M. J. (I960a). The Pseudomonas-Achromobacter group. Can. J. Microbiol. 6,35 .

Moore, H. B. \& Pickett, M. J. (1960 b). Organisms resembling Alcaligenes faecalis. Can. J. Microbiol. $6,43$.

Murray, R. G. E. \& Truant, J. P. (1954). The morphology, cell structure and taxonomic affinities of the Moraxella. J. Bact. 67, 13.

Nagel, C. W., Simpson, K. L., NG, H., Vaughn, R. H. \& Stewart, C. F. (1960). Microorganisms associated with spoilage of refrigerated poultry. Fd. Technol., Champaign I4, 2 I.

Nyberg, C. (1935). Bacillus faecalis alcaligenes Petruschky. Zentbl. Bakt. ParasitKde (Abt I Orig.) I33, 443 .

Paton, A. M. (1959). Enhancement of pigment production by Pseudomonas. Nature, Lond. 184, 1254.

PiÉCHAUd, M. (I96I). Le groupe Moraxella. A propos des B5W-Bacterium anitratum. Annls Inst. Pasteur, Paris roo, Suppl. to no. 6, 74.

Piéchaud, M. (1963). Mobilité chez les Moraxella. Annls Inst. Pasteur, Paris 104, 29 I.

Piéchaud, D., Piéchaud, M. \& Second, L. (1956). Variétés proteolytiques de Moraxella lwoffi et de Moraxella glucidolytica (Bact. anitratum). Annls Inst. Pasteur, Paris 9o, 5 I 7.

Piéchaud, D., Piéchaud, M. \& Second, L. (1951). Étude de 26 souches de Moraxella lwoffi. Annls Inst. Pasteur, Paris 8o, 97

PINTÉr, M. \& BENDE, I. (1967). Computer analysis of Acinetobacter lwoffi (Moraxella lwoffii) and Acinetobacter anitratus (Moraxella glucidolytica) strains. J. gen. Microbiol. 46, 267.

Rhodes, M. E. (1958). The cytology of Pseudomonas spp. as revealed by a silver-plating staining method. J. gen. Microbiol. $\mathbf{1 8}, 639$.

Rosebury, T. (1962). Microorganisms Indigenous to Man. New York: McGraw-Hill.

Ryter, A. \& Kellenberger, E. (I958). Étude au microscope électronique de plasmas contenant de l'acide desoxyribonucléique. $Z$. Naturforsch. $\mathbf{3} b, 597$.

Ryter, A. \& Piéchaud, M. (1963). Étude au microscope électronique de quelques souches de Moraxella. Annls Inst. Pasteur, Paris ro5, 1071.

Schaub, I. \& Hauber, F. E. (I948). A biochemical and serological study of a group of identical Gram-negative bacilli from human sources. J. Bact. 56, 379.

SeEliger, H. (1952/53). Zur Systematik des Bacterium anitratum (Schaub \& Hauber). Zentbl. Bakt. ParasitKde (Abt. I Orig.) r59, 173.

Shewan, J. M., HobBs, G. \& Hodgkiss, W. (1960). A determinative scheme for the identification of certain genera of Gram-negative bacteria, with special reference to the Pseudomonadaceae. J. appl. Bact. 23, 379.

Shewan, J. M., Hodgkiss, W. \& Liston, J. (1954). A method for the rapid differentiation of certain non-pathogenic asporogenous bacilli. Nature, Lond. 173, 208.

Simmons, J. S. (1926). A culture medium for differentiating organisms of typhoid-colon aerogenes groups and for isolation of certain fungi. J. infect. Dis. 39, 209.

Skerman, V. B. D., Carey, B. J. \& MacRae, I. C. (I958). The influence of oxygen on the reduction of nitrite by washed suspensions of adapted cells of Achromobacter liquefaciens. Can. J. Microbiol. 4, 243 .

Smith, R. R., Gordon, R. E. \& Clark, F. E. (1946). Aerobic mesophilic spore-forming bacteria. Misc. Publ. U.S. Dep. Agric. no. 559. Washington, D.C. 
SNEATH, P. H. A. (I957). The application of computers to taxonomy. J. gen. Microbiol. I7, 20 I.

SNEATH, P. H. A (1962). The construction of taxonomic groups. Symp. Soc. gen. Microbiol. 12, 289.

SNeath, P. H. A. \& Sokal, R. R. (I962). Numerical taxonomy. Nature, Lond., r93, 855.

Sokal, R. R. \& SNeath, P. H. A. (1963). Principles of Numerical Taxonomy. San Francisco and London: W. H. Freeman.

Stanier, R. Y., Palleroni, N. J. \& Doudoroff, M. (I966). The aerobic Pseudomonads: a taxonomic study. J. gen. Microbiol. 43, I59.

Steel, K. J. \& Cowan, S. T. (1964). Le rattachement de Bacterium anitratum, Moraxella lwoff, Bacillus mallei et Haemophilus parapertussis au genre Acinetobacter Brisou et Prévot. Annls Inst. Pasteur, Paris ı06, 479.

Stenzel, W. \& Mannheim, W. (I963). On the classification and nomenclature of some nonmotile and coccoid diplobacteria, exhibiting the properties of Achromobacteriaceae. Int. Bull. bact. Nomencl. Taxon. 13, 195.

Stuart, C. A., Formal, S. \& McGanN, V. (I949). Further studies on B5 W, an anaerogenic group in the Enterobacteriaceae. J. infect. Dis. 84, 235.

Sulzbacher, W. L. (1950). Survival of microorganisms in frozen meat. Fd. Technol., Champaign 4, 386.

SzYBALSKI, W. (I952). Gradient plate technique for study of bacterial resistance. Science II6, 46.

Thibault, P. (1961). A propos d'Alcaligenes faecalis. Annls Inst. Pasteur, Paris roo, Suppl. to no. 6,59 .

Thornley, M. J. (I $960 a$ ). The differentiation of Pseudomonas from other Gram-negative bacteria on the basis of arginine metabolism. J. appl. Bact. 23, 37.

Thornley, M. J. (1960 $b$ ). Computation of similarities between strains of Pseudomonas and Achromobacter isolated from chicken meat. J. appl. Bact. 23, 395.

ThORNLEy, M. J. \& HoRNe, R. W. (I962). Electron microscope observations on the structure of fimbriae, with particular reference to Klebsiella strains, by the use of the negative staining technique. J. gen. Microbiol. 28, $5 \mathrm{I}$.

Thornley, M. J., Ingram, M. \& Barnes, E. M. (1960). The effects of antibiotics and irradiation on the Pseudomonas-Achromobacter flora of chilled poultry. J. appl. Bact. 23, 487.

Trevisan, V. (1885). Caratteri di alcuni nuovi generi di Batteriacee. Atti Accad. Fisio-MedicoStatistica, Milano, Ser. 4. 3, 92.

Tulecke, W., Orenski, S. W., Taggart, R. \& Colavito, L. (1965). Isolation of an organism resembling Achromobacter liquefaciens. J. Bact. 89, 905.

Türck, L. (1952). Zur Differenzierung der Bakterien der Alkaligenes Gruppe. Z. Hyg. InfektKrankh. 134, 300 .

VÉron, M., Thibault, P. \& Second, L. (1959). Neisseria mucosa (Diplococcus mucosus Lingelsheim) I. Description bactériologique et étude du pouvoir pathogène. Annls Inst. Pasteur, Paris 97, 497.

Véron, M., Thibault, P. \& SeCOND, L. (196I). Neisseria mucosa (Diplococcus mucosus Lingelsheim) II. Etude antigenique et classification. Annls Inst. Pasteur, Paris, roo, I66.

\section{EXPLANATION OF PLATES}

\section{Plate I}

Fig. I-3. Electron micrographs of intact cells, negatively stained with potassium phosphotungstate.

Fig. I. Strain MJT/F5/I58, the representative strain of Phenon 3. Capsular material $(C)$ and fimbriae $(F)$ are present, and grooves $(G)$ show the positions at which cell division is proceeding. $\times 24,000$.

Fig. 2. Strain MJT/F $4 / 8 / 3$ in Phenon 4 , which consists of cocci in pairs with a very thick capsule $(C)$ and long fimbriae $(F) . \times 28,000$.

Fig. 3. Alcaligenes viscosus NCIB 8596 , in Phenon 4. The cocci are arranged in chains. $\times 24,000$. 
Journal of General Microhiologr, Vol. 49, No. 2

Plate I
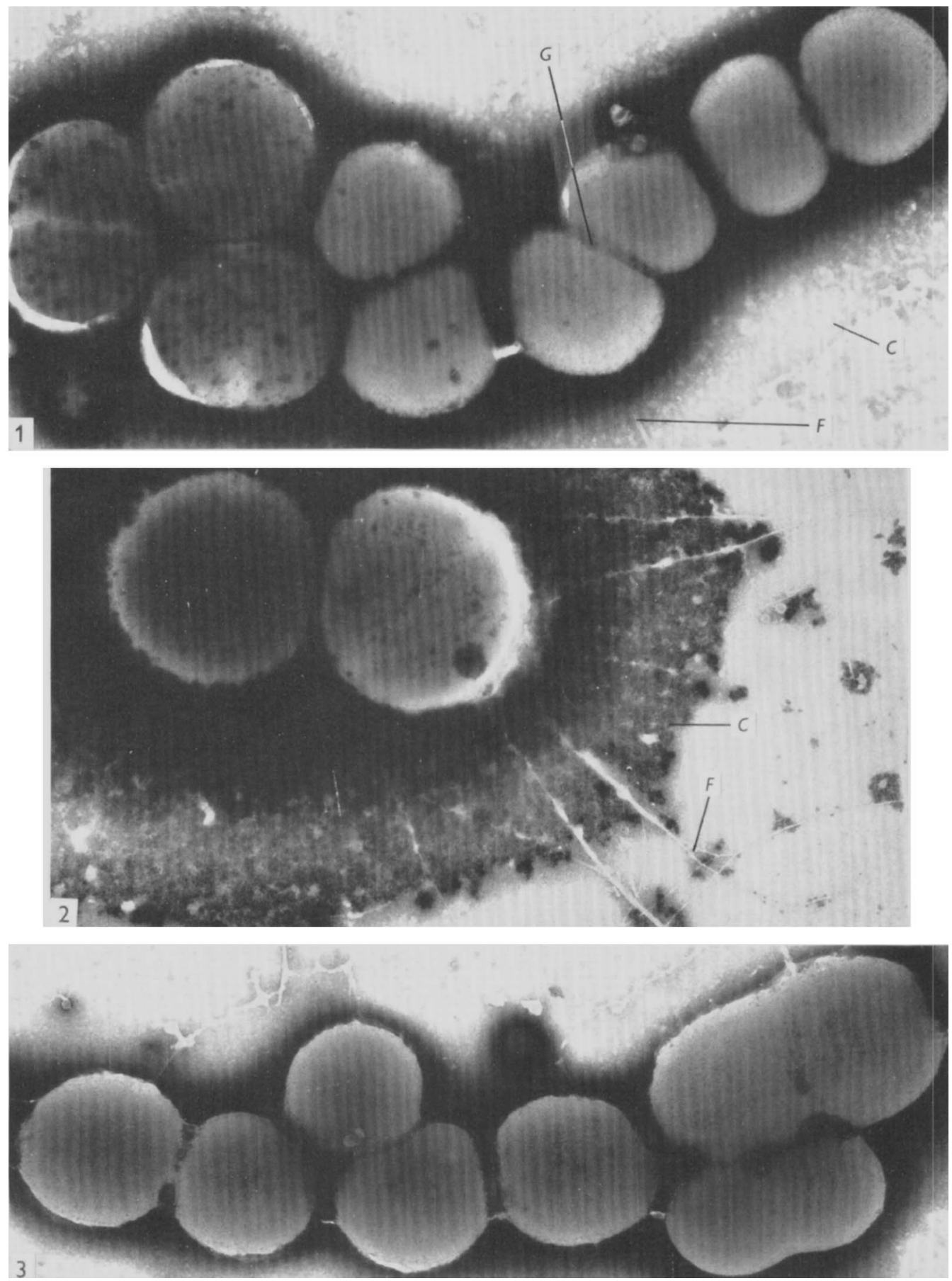

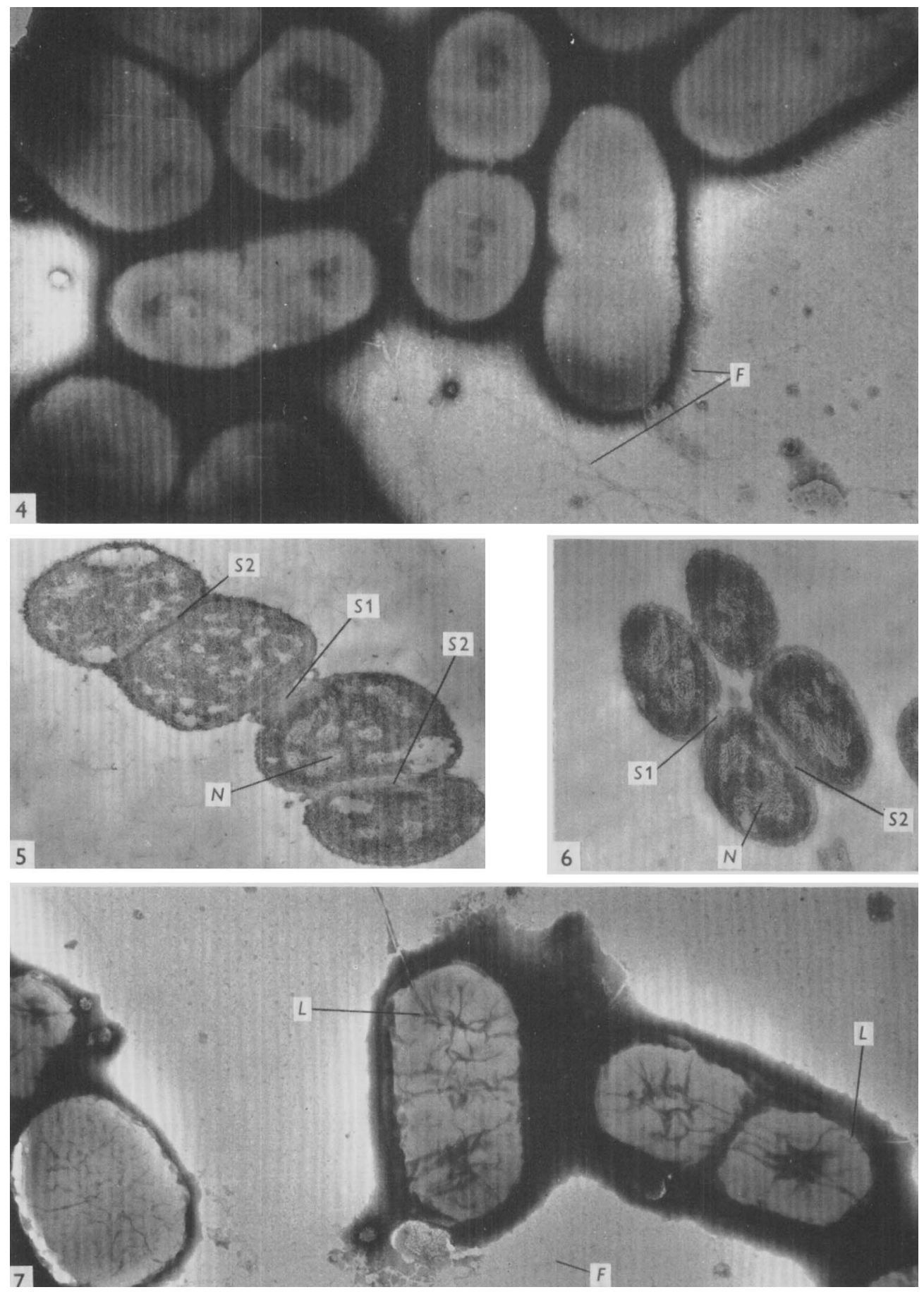

M. J. THORNLEY 
Plate 2

Fig. 4 and 7. Electron micrographs of intact cells, negatively stained with potassium phosphotungstate.

Fig. 5. and 6. Electron micrographs of thin sections of strain MJT/F5/199A in Phenon 4, after different periods of growth in aerated broth.

Fig. 4. Strain MJT/F5/5, in Phenon 4 iii. The cells are coccoid rods and short rods, with fimbriae $(F)$. $\times 28,000$

Fig. 5. Cells from a 10-hr. culture, forming a short chain. The septum marked $S$ I was formed earlier, and later divisions $\left(S_{2}\right)$ are taking place in a plane parallel to the first. N-nuclear material. $\times 20,000$.

Fig. 6. Cells from a $24 \mathrm{hr}$. culture, forming a tetrad. The remaining part of an earlier septum $\left(S_{\mathrm{I}}\right)$ shows a division plane perpendicular to that of the later-formed septum, $S_{2}$. N-nuclear material. 20,000 .

Fig. 7. Intact cells of Alcaligenes faecalis NCTC 655, in Phenon 5, consisting of short rods and coccoid rods. Two flagella with lateral attachment $(L)$ are shown, and fimbriae $(F)$ are present. The surface appearance of this strain, in which the phosphotungstate has penetrated well-marked grooves or wrinkles, differs from that of the non-motile cocci or coccoid rods in Figs. 1-4. $\times 28,000$. 